\title{
Studies of the Earliest Generated Cells of the Cat's Visual Cortex: Cogeneration of Subplate and Marginal Zones ${ }^{1}$
}

\author{
MARLA B. LUSKIN² AND CARLA J. SHATZ \\ Stanford University School of Medicine, Stanford, California 94305
}

\begin{abstract}
The earliest generated cells of the cat's telencephalon that may play a role in the formation of the primary visual cortex are the subject of this study. Using $\left[{ }^{3} \mathrm{H}\right]$ thymidine autoradiography, we have found that these cells are generated between embryonic day 24 (E24) and E30 (gestation is 65 days) and that they are present in very low numbers in the white matter of the adult brain. These cells are rarely labeled by injections made after E30, when the cells destined for the cortical layers are generated.

Examination of the labeling pattern in the fetal brain $\mathbf{1 0}$ days or more after administration of $\left[{ }^{3} \mathrm{H}\right]$ thymidine between E24 and E30 revealed a bistratified distribution of these early generated cells. Labeled cells were found in large numbers in two embryonic zones flanking the developing cortical plate: above in the marginal zone and below in the subplate. (Some if not all of the marginal zone cells constitute the population of Cajal-Retzius cells of the cat's telencephalon.). These experiments indicate that cells of the subplate and marginal zones are cogenerated in time during the days just preceding the genesis of the cortical plate. We also examined the distribution of the early generated cells shortly after their genesis-on E30, a time when cells of the cortical plate are just being generated at the ventricular zone. In this case, the labeling pattern at the occipital pole was not bistratified. Rather, labeled cells were situated within a single zone extending from the pial surface inward to the border of the ventricular zone. This finding indicates that the cells of the subplate and marginal zones are generated as a contiguous population that is subsequently split apart by the insertion of cells forming the cortical plate.

A comparison between the number of early generated cells found in fetal and newborn brains with that found in adult brains suggests that these cells are generated initially in substantial numbers but then largely disappear during early postnatal life, since injections of $\left[{ }^{3} \mathrm{H}\right]$ thymidine between E24 and E30 yielded large numbers of labeled cells in the white matter and layer 1 at birth, but very few at 2 months postnatal.
\end{abstract}

Received June 18, 1984; Revised September 4, 1984;

Accepted September 11, 1984

' We are grateful to Drs. C. Goodman, P. Rakic, S. L. Shotwell, and D. W. Sretavan, for their valuable criticisms of the manuscript. We wish to thank Mark Siegel and Angela DiBerardino for their assistance with the histology and Cecele Thomas for secretarial help. This work was supported by National Institutes of Health Grant EY 02858 to C. J. S. and Grant NS 07158 to M. B. L.

${ }^{2}$ To whom correspondence should be sent, at her present address: Vision Center Laboratory, Salk Institute for Biological Studies, P. O. Box 85800, San Diego, CA 92138.
This significant loss contrasted with the results from injections made just a few days later (E33) that resulted in large numbers of labeled cells in cortical layer 6 not only at birth but also in adulthood. Due to the close proximity of the cells in layer $\mathbf{6}$ and those of the white matter, it is unlikely that the disappearance of white matter cells is due solely to differential growth of the brain. The temporary nature of these early generated cells and their close relationship with the cells of the cortical plate throughout fetal development suggest that this special bistratified population may provide a cellular framework for the development of the cortical plate itself.

The steps that lead to the formation of the adult vertebrate nervous system from its embryonic precursors are complex and often leave no trace in the adult. For example, there are several instances in which specific classes of cells are present during development but do not persist into adulthood. One of the best known is the radial glial cell of the mammalian central nervous system. These glial cells have been shown by morphological and immunohistochemical methods to extend from ventricular to pial surface during fetal life, but they are not found in the adult brain (Rakic, 1972; Levitt and Rakic, 1980). Familiar cases of neurons that have a transient existence include the Rohon-Beard neurons of the amphibian spinal cord (Spitzer and Lamborghini, 1981) and the Cajal-Retzius cells of the mammalian cerebral cortex (Ramion y Cajal, 1890, 1929; Noback and Purpura, 1961; Duckett and Pearse, 1968; Sas and Sanides, 1970; Marin-Padilla, 1971; Bradford et al., 1977). In each case, these cells are among the earliest generated based on tritiated thymidine $\left({ }^{3} \mathrm{H}\right]$ thymidine) autoradiography and are among the earliest to differentiate based on Golgi studies. Yet neither of these types can be found in the adult nervous system, and their disappearance has been attributed to cell death.

Here we report on another class of cells present in abundance within the mammalian telencephalon during fetal development but rarely found in the adult. We noted these cells in the course of a $\left[{ }^{3} \mathrm{H}\right]$ thymidine study of visual cortical neurogenesis in the cat (Luskin and Shatz, 1982; M. B. Luskin and C. J. Shatz, manuscript in preparation), where we found that administration of $\left[{ }^{3} \mathrm{H}\right]$ thymidine during the 1 -week fetal period preceding the genesis of visual cortical cells labeled a small population of cells embedded in the white matter of the adult. In contrast, $\left[{ }^{3} \mathrm{H}\right]$ thymidine given later on labeled large numbers of cells situated in the cortical layers. This difference in numbers made us wonder whether the white matter cells might be produced in large numbers and then undergo a reduction by adulthood analogous to that for the Cajal-Retzius cells.

To study this possibility, we have used the method of $\left[{ }^{3} \mathrm{H}\right]$ thymidine autoradiography to follow and compare the developmental history of these early generated cells of the white matter and the Cajal-Retzius cells. The results presented here indicate that both sets of cells are generated in large numbers, although very few in 
either case persist into adult life. Moreover, the white matter cells and the Cajal-Retzius cells are generated concurrently as a contiguous population-the earliest generated population of the telencephalon-that is later split apart by the subsequent accretion of cells forming the cortical plate. These observations suggest that both sets of early generated cells may provide a framework for the development of the cortical plate that largely disappears when the process is complete. A preliminary report of this work has appeared previously (Luskin and Shatz, 1983).

\section{Materials and Methods}

The brains of 50 animals exposed to tritiated thymidine $\left(\left[{ }^{3} \mathrm{H}\right]\right.$ thymidine) during embryonic life were studied. Since we wished to examine the genesis, distribution, and fate of the early generated cells of the cerebral cortex, two sets of experiments were carried out. In the first set, animals given $\left[{ }^{3} \mathrm{H}\right]$ thymidine were examined at later fetal or neonatal times. In the second set, postnatal animals were studied when they reached at least 2 months of age-a time when the cytoarchitecture and connectivity of the visual cortex are adult-like (Cragg, 1972; LeVay et al., 1978).

Fetuses of known gestational ages were obtained by breeding a female cat in estrus with an experienced male for either 24 or $48 \mathrm{hr}$. (For a 24-hr breeding, the day of breeding was counted as day 1 of the cat's 65-day gestation, whereas for a 48-hr breeding, the second day of breeding was counted as day 1 of gestation). A 24-hr breeding was chosen when it was desirable to obtain optimal time resolution. Even with 24-hr breedings, the uncertainty in gestational age is \pm 1 day due to the cat's reproductive biology (Scott, 1970). Nevertheless, this procedure provided fetuses whose gestational age could be determined with the degree of precision necessary for this study (see Shatz, 1983).

Surgical procedure. Cesarian sections were performed using sterile surgical techniques in order to expose the uterus for injections of $\left[{ }^{3} \mathrm{H}\right]$ thymidine. A pregnant female cat was first administered ketamine hydrochloride (20 $\mathrm{mg} / \mathrm{kg}$ ) and acepromazine $(0.2 \mathrm{mg} / \mathrm{kg})$ intramuscularly to induce anesthesia. and atropine sulfate $(0.05 \mathrm{mg} / \mathrm{kg}, \mathrm{i}, \mathrm{m}$.) was also given. Anesthesia was sustained by a combination of halothane $(0.5$ to $1.5 \%)$, nitrous oxide, and oxygen (0.3:1 liters/min) delivered through an endotracheal tube; the respired $\mathrm{CO}_{2}$ was monitored continuously. Terbutaline sulfate $(0.03 \mathrm{mg} / \mathrm{kg})$ and $5 \%$ dextrose in Ringer's solution were administered intravenously (Shatz, 1983). The procedure followed here for making direct intrauterine injections of $\left[{ }^{3} \mathrm{H}\right]$ thymidine was adapted from Hickey et al. (1983). The uterus was exposed by a midline abdominal incision, and thymidine was injected into the amniotic cavity of each fetus to be studied through a tuberculin syringe attached to a 26 gauge needle. The abdomen was sutured closed and the cat was revived. This procedure did not interfere with a normally timed delivery of newborn kittens around E65. Five additional pregnant females (anesthetized) received an intravenous injection of $\left.{ }^{3} \mathrm{H}\right]$ thymidine.

Thymidine injections. The standard amount of tritiated thymidine (New England Nuclear, NET 027Z, [methyl. ${ }^{3} \mathrm{H}$ ]thymidine, 50 to $80 \mathrm{Ci} / \mathrm{mmol}$ ) in sterile physiological $(0.9 \%)$ saline delivered by intravenous injection was 10 $\mathrm{mCi} / \mathrm{kg}$ of body weight of the pregnant female (Nowakowski and Rakic, 1974). For the intrauterine injections, $5 \mu \mathrm{Ci}$ to $1.5 \mathrm{mCi}$ were injected depending on the gestational age. A summary of the specific amount and volume of thymidine injected at cach experimental age is given in Table I.

Histology. Thirty-one animals were collected prenatally and 19 postnatally, of which 5 were newborn. All fetal animals were removed by cesarian section, and all were transcardially perfused using a peristaltic pump. The circulatory system was flushed with $0.1 \mathrm{M}$ phosphate buffer $(\mathrm{pH} \mathrm{7.4)}$ followed by a solution of $4 \%$ paraformaldehyde and $5 \%$ sucrose in $0.1 \mathrm{M}$ phosphate buffer (pH 7.4). Crown-rump measurements were taken to ensure that all fetuses were of average size for their gestational age (Shatz, 1983). Brains were removed and postfixed at $4^{\circ} \mathrm{C}$ in $4 \%$ paraformaldehyde in $0.1 \mathrm{M}$ phosphate buffer ( $\mathrm{pH} 7.4$ ) to which $20 \%$ (fetuses) or $30 \%$ (adults) sucrose was added. Brains were then embedded in a gelatin-albumin mixture and sectioned on a freezing microtome at $20 \mu \mathrm{m}$ in the horizontal or coronal plane. The sections were dipped in NTB-2 emulsion, exposed from 1 week to several months, and then developed in D-19. Usually, every other section was counterstained with cresyl violet before coverslipping. The material was examined and analyzed in brightfield or darkfield, and selected areas were recorded by camera lucida drawings. This study also illustrates the results from one animal found dead at birth (E27 to PO). Although, upon microscopic examination, the cells in this brain appeared pyknotic as judged by their small round shape and dense staining. we nonetheless felt comfortable about including this case in the study because (1) the labeled cells could still be recognized in the usual way by a cluster of silver grains overlying
TABLE I

Amount of $\left[{ }^{3} \mathrm{H}\right]$-thymidine injected at the various fetal ages studied

\begin{tabular}{cllc}
\hline $\begin{array}{c}\text { Age at } \\
\text { Injection }\end{array}$ & \multicolumn{1}{c}{$\begin{array}{c}\text { Amount } \\
(\mathrm{mCi})\end{array}$} & $\begin{array}{c}\text { Volume } \\
(\mathrm{ml})\end{array}$ & $\begin{array}{c}\text { Total No. of } \\
\text { Animals }\end{array}$ \\
\hline E17 & i.v. & & $2^{a}$ \\
E18 & 0.005 & 0.05 & 1 \\
E19 & i.v. & & $5^{a}$ \\
E20 & 0.1 & 0.025 & 1 \\
E21 & $0.007-0.02$ & $0.07-0.2$ & 2 \\
E24 & or i.v. & & $1^{a}$ \\
E26 & $0.125-0.25$ & $0.05-0.25$ & 6 \\
E27 & $0.3-0.5$ & $0.03-0.1$ & 8 \\
E28 & $0.5-1.0$ & $0.05-0.1$ & 2 \\
& $0.75-1.0$ & 0.1 & 2 \\
E29 & or i.v. & & $3^{a}$ \\
E30 & 0.5 & 0.1 & 1 \\
E31 & $0.5-1.0$ & $0.05-0.2$ & 6 \\
E33 & 0.5 & 0.05 & 2 \\
E37 & $0.5-0.75$ & $0.1-0.15$ & 3 \\
E42 & 0.75 & 0.15 & 1 \\
E43 & 1.0 & 0.1 & 1 \\
& 1.5 & 0.15 & 1 \\
E46 & or i.v. & & $1^{a}$ \\
\hline
\end{tabular}

${ }^{a}$ Number of fetuses in which thymidine was administered intavenously (i.v.) at $10 \mathrm{mCi} / \mathrm{kg}$ to the mother.
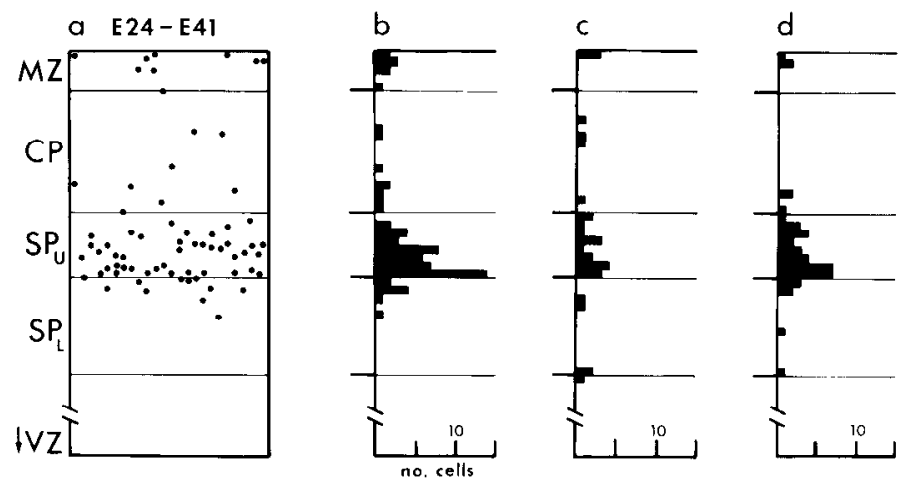

Figure 1. Illustration showing the method of representing the distribution of heavily labeled cells at different relative depths in the presumptive visual cortex on E41 following $\left[{ }^{3} \mathrm{H}\right]$ thymidine injection on E24. $a$ is the result of transferring the information from a camera lucida drawing of labeled cells (black dots) onto a standardized grid of cortex. $b$ summarizes the results of $a$ in histogram form. The histograms of $c$ and $d$ were constructed in the same way from similar grids made from camera lucida drawings of the two adjacent sections. All three histograms were combined to give the composite histogram shown in Figure 8. See "Materials and Methods" for more details. The grid and histograms are subdivided into embryonic zones which are histologically defined under "Results." $C P$, cortical plate; $M Z$, marginal zone; $S P_{L}$, lower portion of subplate; $S P_{U}$, upper portion of subplate; $V Z$, ventricular zone. The downward-pointing arrow indicates that the full extent of the ventricular zone is not included here.

their nuclei ${ }_{i}(2)$ the overall labeling pattern was entirely consistent with our other findings, and (3) it fell in the normal range by crown-rump measurements.

The developing visual cortex in the fetal brain was assumed to be located in the same relative position as in the adult: in the anterior-posterior dimension, between the dorsal lateral geniculate nucleus and the posterior pole of the cerebrai cortex, and in the dorsoventral dimension, along the medial bank of the lateral gyrus from its apex ventralward but no farther than the first sulcus (presumptive splenial sulcus). In view of these specifications, we believe that our study consists principally of area 17 , although we also may have included part of nearby area 18 on occasion. In the adult cases studied, area 17 could be accurately determined according to the criteria of Tusa et al. (1978), and the border with area 18 could be located using the criteria of Otsuka and Hassler (1962)

Construction of histograms. Certain points in the study are summarized 
E 28-P78

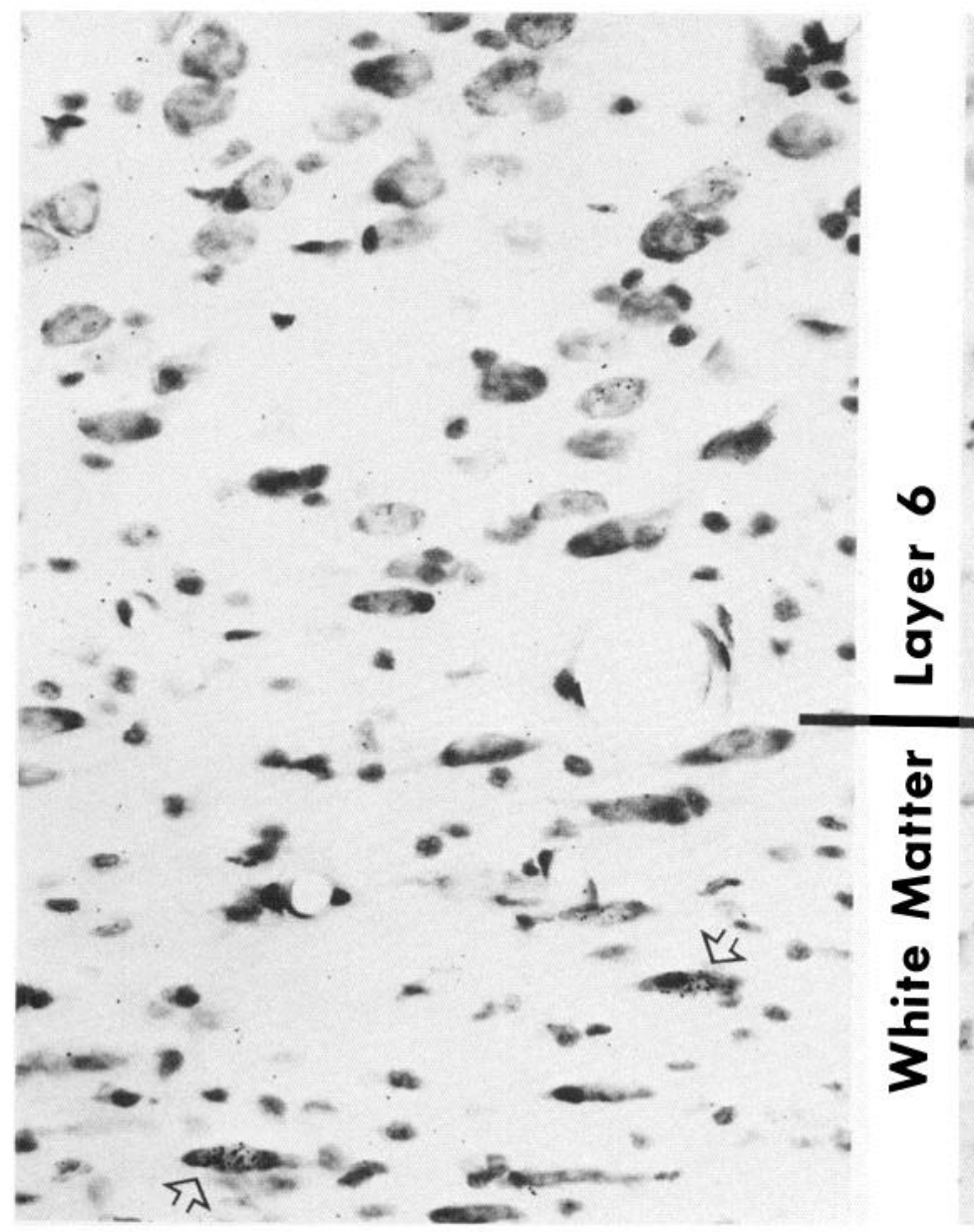

E33-P62

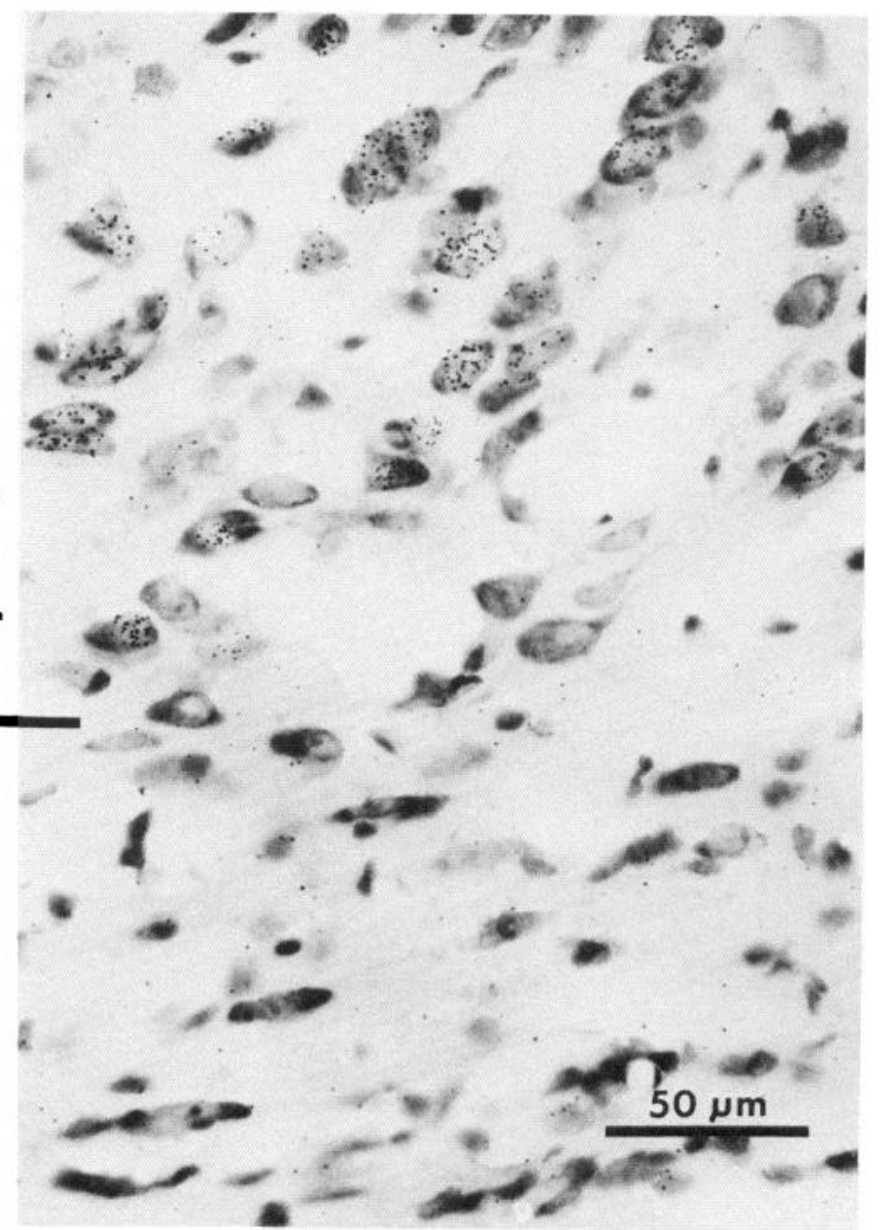

Figure 2. Autoradiographs counterstained with cresyl violet to compare the morphology and position of heavily labeled cells in adult visual cortex resulting from a $\left[{ }^{3} \mathrm{H}\right]$ thymidine injection on E28 (left) or E33 (right); brightfield optics. Labeled cells are embedded in the white matter (open arrows) after an injection on E28 and in layer 6 after an injection on E33. The two labeled white matter cells (right) are elongated parallel to the fiber bundles running in the white matter, in contrast to the pyramidal appearance of labeled cells in layer 6 (left). These high power photomicrographs come from the regions circumscribed by boxes in Figure 3.

in the form of histograms representing the distribution of labeled cells at different relative depths in the presumptive visual cortex following $\left[{ }^{3} \mathrm{H}\right]$ thymidine injections at particular embryonic ages. The manner in which these histograms were constructed is illustrated in Figure 1. First, a series of camera lucida drawings of the distribution of heavily labeled cells was made from three sections, each containing presumptive visual cortex (not shown). (A cell was considered heavily labeled if it contained at least half the maximum number of silver grains found in the most heavily labeled cells in that case.) Next, the information contained in each camera lucida drawing was transferred to a standardized grid (Fig. 1a). The grid was constructed by first making a series of camera lucida drawings of cresyl violet-stained sections through the telencephalon at the embryonic age of interest (in this case, E41) to locate each embryonic layer. (See "Results" for the histological criteria used in establishing the borders between embryonic layers.) Then, the relative dimensions of each layer were estimated and the average values were used to subdivide the telencephalon from pial to ventricular surface, generating the grid. Finally, each heavily labeled cell encountered was plotted onto the grid at its correct relative depth in the brain. An example of results plotted in grid form is shown in Figure 1a. (Here, an animal received a $\left.{ }^{3} \mathrm{H}\right]$ thymidine injection at E24 and was studied at E41.) Each labeled cell was plotted from left to right onto a separate lane of the grid in order to prevent cells at the same relative depth from overlapping one another. (It should be noted that this transformation preserves depth information while losing nearest-neighbor relationships.) Next, the number of cells at each depth was tallied and represented in histogram form as shown in Figure $1 b$. The histograms of Figure 1, $c$ and $d$, were constructed in the same fashion from similar grids made from camera lucida drawings of the two adjacent sections.
Finally, all three histograms were combined to produce the composite histogram distribution of labeled cells shown in Figure 8.

\section{Results}

Location of early generated cells in adult. The pattern of neurogenesis of the cat's primary visual cortex, like that of other mammals (Rakic, 1974, 1977; Shoukimas and Hinds, 1978; Caviness, 1982), is inside-out, with the neurons of layer 6 generated earliest, beginning around E30, and those of the superficial layers generated last, ending around E57 (Luskin and Shatz, 1982; M. B. Luskin and C. J. Shatz, manuscript in preparation). When $\left[{ }^{3} \mathrm{H}\right]$ thymidine is given any time during the week prior to the onset of cortical neurogenesis, few if any labeled cells can be found in cortical layer 6 . However, such injections consistently label a sparse population of cells embedded in the white matter, as well as the occasionall cell in layer 1.

This point is illustrated in Figure 2, photographs of two autoradiographs showing the position of heavily labeled cells resulting from $\left[{ }^{3} \mathrm{H}\right]$ thymidine injections at E28 (Fig. 2, left) and E33 (Fig. 2, right). For example, within the white matter, two heavily labeled cells can be seen following an injection at E28 (Fig. 2, open arrows), whereas no heavily labeled cells are present in cortical layer 6 . In contrast, an injection just 5 days later at E33 did not label any white matter cells but, as shown in Figure 2 (right), produced heavy labeling of overlying cortical layer 6 . Thus, it appears that the genesis of cells 
E28-P78

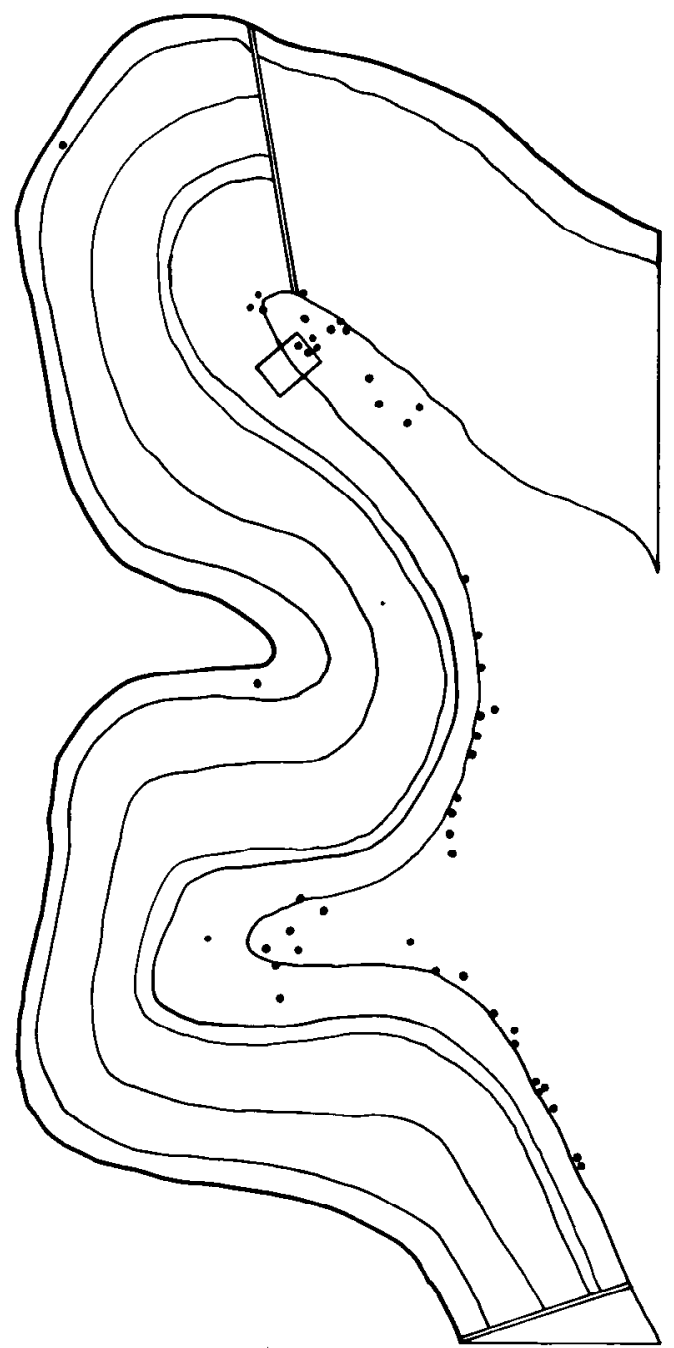

E33-P62

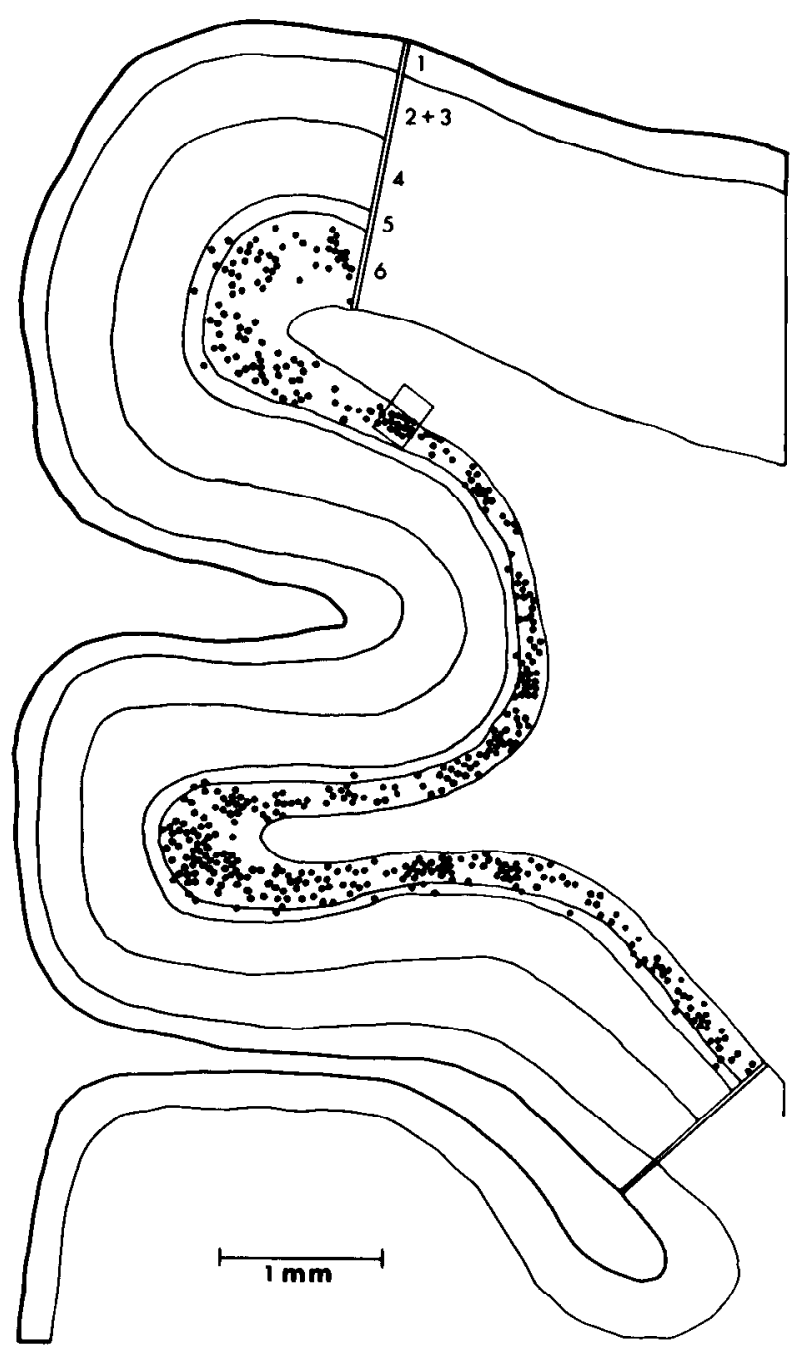

Figure 3. Camera lucida drawings of representative autoradiographs of adult primary visual cortex (delimited by double lines) to compare the distribution and density of heavily labeled cells (black dots) resulting from $\left[{ }^{3} \mathrm{H}\right]$ thymidine injection on E28 (left) or E33 (right). Note the greater number of heavily labeled cells at E33. The E28 section was purposely chosen because an unusually large number of labeled cells resulted from such an early injection. Both sections were selected from a coronal plane passing through the midportion of the lateral geniculate nucleus. Numbers indicate layers 1 to 6 . Boxes indicate locations of photographs in Figure 2.

of the white matter actually precedes that of cortical layer 6 by several days.

Not only are these two classes of cells generated over slightly different periods of time, but they also can be distinguished from each other on the basis of their morphological appearance in cresyl violet-stained sections. Cells destined for the white matter are often quite large and are frequently elongated into spindle shapes with the long axis parallel to fiber bundles running in the white matter. The two heavily labeled cells shown in Figure 2 (left) exemplify this characteristic morphology. It is noteworthy that the majority of white matter cells labeled by $\left[{ }^{3} \mathrm{H}\right]$ thmidine any time between E24 and E30 have this characteristic shape in the adult which is distinctly different from the typical pyramidal-shaped appearance of the cells of cortical layer 6 (cf. Fig. 2, E28 and E33).

Another striking difference between the white matter cells and those of layer 6 is in the total number of labeled cells found in the adult. This difference is shown in Figure 3, which contains camera lucida drawings of representative autoradiographs of the primary visual cortex subsequent to $\left[{ }^{3} \mathrm{H}\right]$ thymidine administration at E28 or E33. In each drawing, black dots depict the location of heavily labeled cells throughout the entire mediolateral extent of area 17.
These drawings demonstrate that far more labeled cells are present in the adult following an injection at E33 than at E28. Here (Fig. 3) we counted 470 labeled cells in layers 5 and 6 in the E33 case versus only 44 cells in the white matter, layer 6 , and layer 1 in the E28 case. This disparity in the number of labeled cells found in the adult was seen whenever the results of injections made before and after E30 were compared. Thus, any injection that labeled cells of the cellular layers of the visual cortex yielded numbers comparable to those illustrated at E33 (Luskin and Shatz, 1982; M. B. Luskin and C. J. Shatz, manuscript in preparation). In contrast, cells of the white matter were labeled in substantially fewer numbers with injections made between E24 and E30. Indeed, it was often the case that only a few labeled cells per section were present, and, in fact, the section represented in Figure 3 at E28, purposely selected for illustration, contains an unusually large number.

The apparent paucity of labeled cells following a $\left[{ }^{3} \mathrm{H}\right]$ thymidine injection any time before E30 stands in marked contrast to the large numbers of labeled cells found in the cortical layers later on. This contrast is particularly intriguing because the injections given prior to E30 always effectively labeled many populations of cells elsewhere in the brain, indicating that availability of $\left[{ }^{3} \mathrm{H}\right]$ thymidine was 


\section{E27-PO}
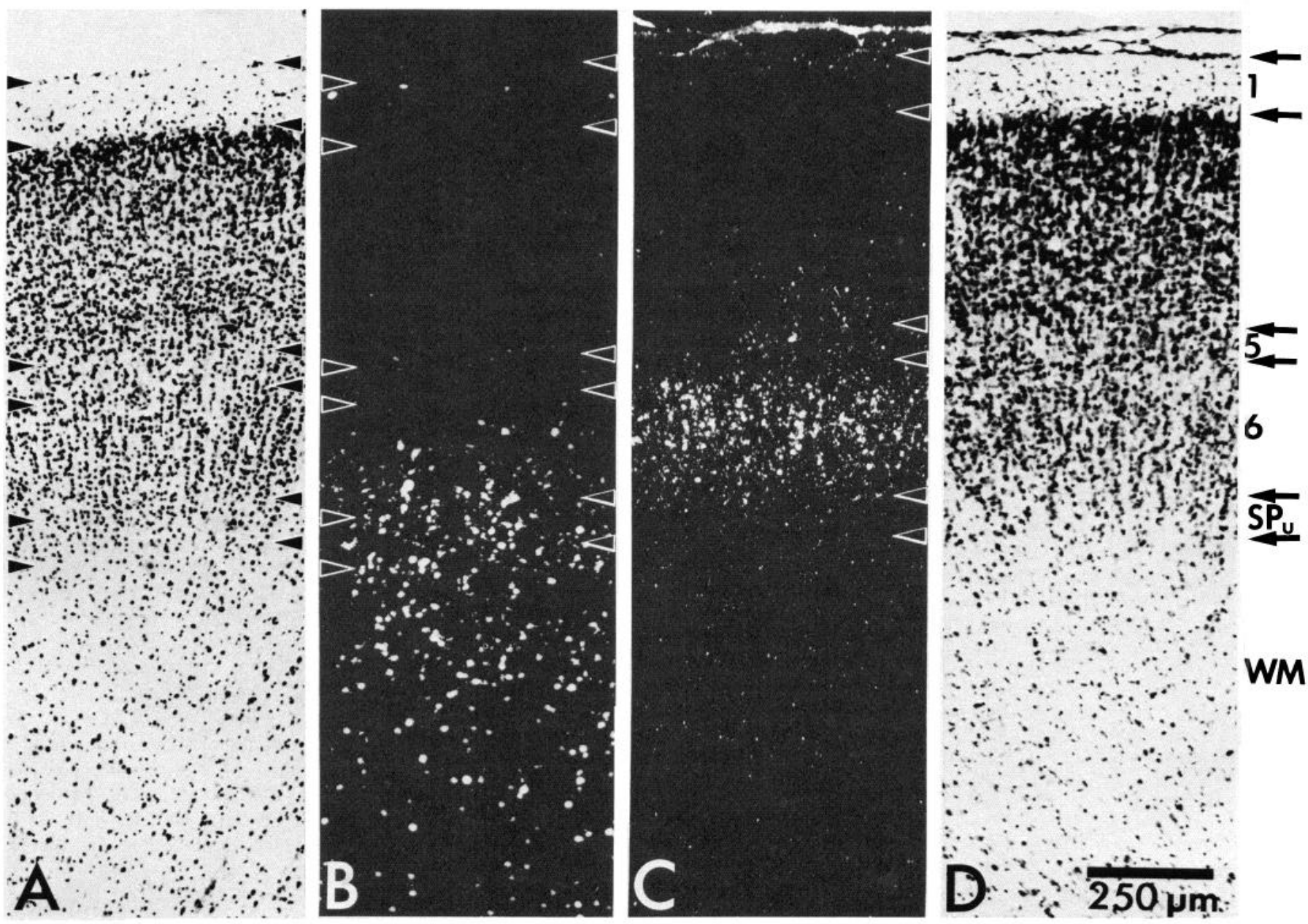

Figure 4. The distribution of heavily labeled cells at birth resulting from $\left[{ }^{3} \mathrm{H}\right]$ thymidine injections on $\mathrm{E} 27(A$ and $B)$ or $\mathrm{E} 33(\mathrm{C}$ and $D)$. $B$ and $C$ show the autoradiographic labeling pattern in darkfield photomicrographs, and $A$ and $D$ illustrate adjacent cresyl violet-stained sections to show the histological composition of the visual cortex at birth, when it is possible to identify layers 1,5 , and $6 . C$ and $D$ show that $\left[{ }^{3} \mathrm{H}\right.$ ]thymidine given on E33 results in a band of labeled cells at the base of the cortical plate corresponding to layers 5 and 6 , whereas $\left[{ }^{3} H\right]$ thymidine given on E27 $(A$ and $B)$ labels cells of the white matter (WM) below layer 6 . Some labeled cells also occur within layers 1 and 6 after the E27 injection. The laminar boundaries are marked by arrowheads along the inside border of each panel. The calibration bar in $D$ applies to all panels. The zone marked $S P_{u}$ contains cells that do not contribute to the adult cortex, and consequently this zone is not considered a part of the cortical plate.

not a problem (Hickey and Cox, 1979; Shatz, 1981). One possibility is that on the days between E24 and E30, white matter cells are generated in numbers equivalent to those for the cortical layers, but, for some reason, many of these cells disappear by adulthood, much like the familiar Cajal-Retzius cells of layer 1 (Ramón y Cajal, 1890, 1911: Sas and Sanides, 1970; Edmunds and Parnavelas, 1982). The remaining experiments described in this paper were designed to investigate this possibility.

Numbers and location of early generated cells at birth. If cells of the white matter and cortex are initially generated in roughly similar numbers, then it should be possible to find times prior to adult life when they are labeled in comparable numbers after $[3 \mathrm{H}]$ thymidine administration. The experiment described below suggests that this is very probably the case. Here, $\left[{ }^{3} \mathrm{H}\right]$ thymidine was given to two fetuses as before, in order to label the white matter cells on the one hand (E27) and the cells of layer 6 on the other (E33). This time, however, the animals were studied at birth rather than in adulthood, and the results are shown in the photomicrographs of Figure 4. At each age, the distribution of labeled cells is shown in darkfield autoradiographs. Each autoradiograph is accompanied by an adja- cent section stained with cresyl violet to designate the laminar location of label. As can be seen from the cresyl violet-stained sections here, the cortex is histologically immature at birth; nevertheless, it is possible to identify future layers 1,5 , and 6 . Thus, as expected, $\left[{ }^{3} \mathrm{H}\right]$ thymidine given at E27 principally labeled cells of the white matter and some cells of future layers 6 and 1 , whereas $\left[{ }^{3} \mathrm{H}\right]$ thymidine at E33 labeled cells of the cortical plate within future layers 5 and 6.

The major difference between the results of this experiment and those in the adult was in the number of labeled cells found in the white matter: significantly more were present at birth. This finding can be best appreciated by comparing the camera lucida drawing of the section through adult area 17 in Figure 3 with that in Figure 5, which shows the distribution of labeled cells at birth. Not only were there many more white matter cells at birth than adulthood, but also at birth the number of labeled cells following an injection at E27 was remarkably similar to that resulting from the injection made at E33 (Fig. 5: number of labeled cells in E27 section $=332$; number of labeled cells in E33 section $=335$ ). Taken together, these results support the proposal that cells of the white matter are generated in 

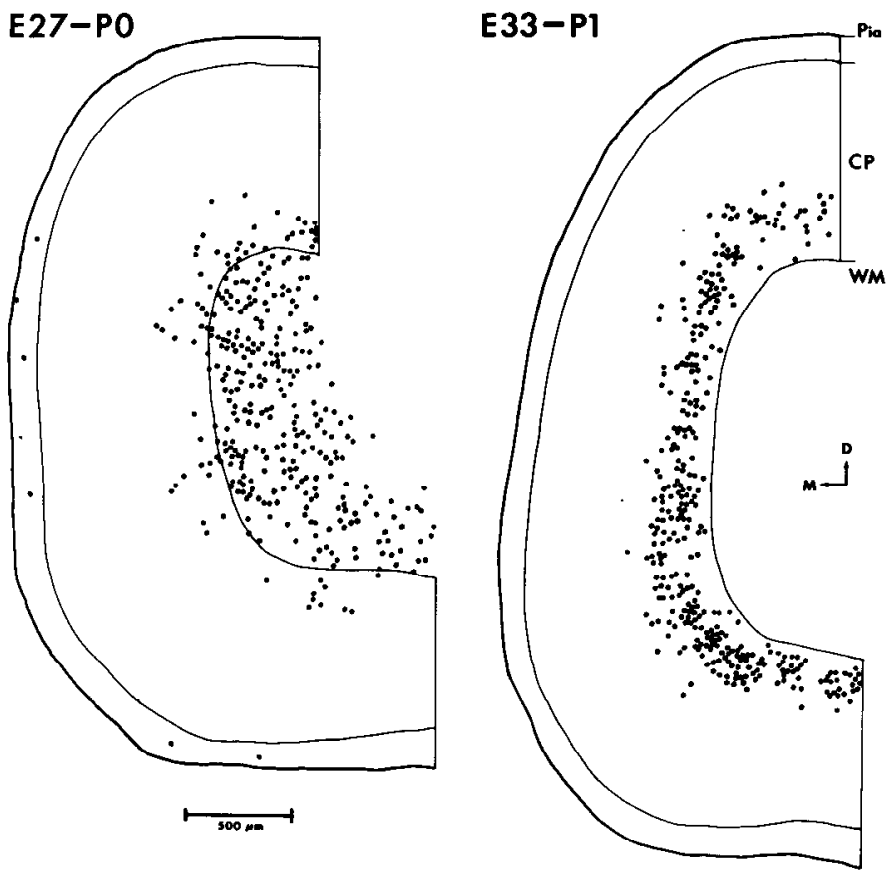

Figure 5. Camera lucida drawings of representative autoradiographs to show the distribution of heavily labeled cells (black dots) in the visual cortex at birth resulting from $\left.{ }^{3} \mathrm{H}\right]$ thymidine injection on E27 (left) or E33 (right) as seen in a coronal section coinciding with the midportion of the lateral geniculate nucleus. Roughly comparable numbers of labeled cells are found after an injection on E27 (332) and E33 (335), although they are situated within the cortical plate $(C P)$ after the E33 injection (right), and predominantly below it after the E27 injection. Labeled cells are also present in layer 1 after the E27 injection, but not after the injection on E33. Dorsal $(D)$ is up and medial $(M)$ is to the left. WM, white matter. The calibration bar refers to both drawings.

numbers roughly equivalent to those of the cortical layers and that some time between birth and adulthood there is a differential loss of the white matter cells.

Time course of genesis of white matter cells. The fact that the genesis of white matter cells precedes that of the cortical plate and that a dirninshed number of white matter cells persists into adulthood suggests that this earliest generated population may play a special role during development. We were therefore motivated to study the time course and pattern of genesis of these cells in more detail.

The first question we addressed was whether the period of genesis for the white matter cells derived from the adult studies (E24 to E30) was an accurate indication of the total period. This issue was of some concern because it could be that white matter cells are generated even earlier than E24 but none persist into adult life. Alternatively, a subpopulation of cells generated at every age after E30 might contribute to the white matter, but again, none of these survive into adulthood. Both of these alternatives were investigated by making $\left[{ }^{3} \mathrm{H}\right]$ thymidine injections either prior to E24 or following E30 and then examining the fetal telencephalon autoradiographically. To address the first alternative, fetuses were injected with $\left[{ }^{3} \mathrm{H}\right]$ thymidine at E17,E19, E20, and E21 and then examined either at $E 31$ ( $E 17$ to $E 31 ; E 19$ to $E 31$ ) or $E 48$ (E20 to E48; E21 to E48). E31 was chosen for examination because it is the earliest time that a cortical plate can be recognized in the occipital pole. None of these injections produced labeled cells anywhere in the occipital pole, although many labeled cells were found in subcortical structures. This result indicates that genesis of white matter cells begins after E21 and, further, that a transient population of white matter cells is not generated prior to E24.

To address the second alternative-that white matter cells are generated in concert with those of the cortical plate but subsequently disappear-another series of seven fetuses older than E30 was

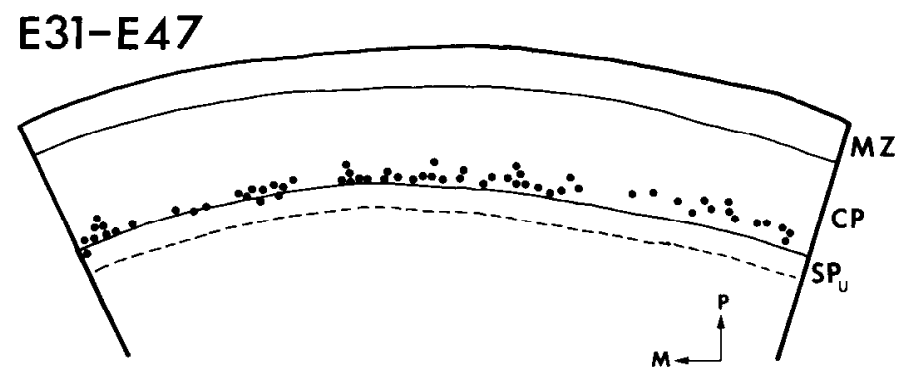

Figure 6. Camera lucida drawing of a representative autoradiograph of the presumptive visual cortex at E47 to illustrate the distribution of heavily labeled cells (black dots) following a [ ${ }^{3} \mathrm{H}$ ]thymidine injection on $\mathrm{E} 31$. Labeled cells are situated at the base of the cortical plate $(C P)$, superficial to the upper half of the subplate ( $S p_{u}$ : future white matter). Note that this is in contrast to the labeling pattern following injections given between E24 and E30 (see Figs. 8, 9, and 13). $M Z$, marginal zone. $P$ (posterior) points in the direction of the posterior pole, and $M$ (medial) points toward the midline in this horizontal section.

injected, and again, the fetal telencephalon was examined autoradiographically. Fetuses were injected at E31, E33, E37, E42, E43 (two), and E46 and survived 2 to 4 weeks, sufficient time for those $\left[{ }^{3} \mathrm{H}\right]$ thymidine-labeled cells destined to belong to a cortical layer in the adult to migrate into the cortical plate. In these cases, labeled cells were seldom found below the developing cortical plate in the future white matter, although in each case, a band of labeled cells was always seen at an appropriate depth within the cortical plate. These points are illustrated in Figures 6 and 13. In both cases, $\left[{ }^{3} \mathrm{H}\right]$ thymidine was injected at times known to produce, in the adult, labeled cells in cortical layer 6 (Fig. 6, E31) or cortical layers 4 and 5 (Fig. 13, E37). Just 2 to 4 weeks after the injections, labeled cells are already located in clear strata within the cortical plate, whereas very few are situated below, in the region of the future white matter (Figs. 6 and 13, $S P_{U}$ ). These results, then, suggest that the period of genesis of white matter cells is largely complete by E30. Thus, genesis of white matter cells is essentially restricted to the 1 -week period extending from E24 to E30.

Position of early generated cells in the fetus. In order to learn more about the role played by cells generated between E24 and E30, it was of interest to examine the location of this population of cells within the developing telencephalon. To do so, we first labeled cells at E26, in the middle of the genesis period to optimize labeling, and then examined their position at a time when the cortical plate is easily recognizable in the occipital pole-at E40. The results of this experiment are shown in the photomicrographs of Figure 7. As can be seen in the darkfield autoradiograph on the left in Figure 7, heavily labeled cells are present in two zones, one near the pial surface (arrows point to two labeled cells) and the other at the base of the cortical plate. On the right in Figure 7 is an adjacent cresyl violetstained section to show the histological appearance at this age. At the far right in Figure 7 we have identified the various embryonic layers evident here according to the conventions and nomenclature of the Boulder Committee (1970) as they have been modified by Rakic (1982). Thus, in Figure 7 the developing telencephalon is subdivided into a marginal zone $(M Z$, future layer 1$)$, cortical plate $(C P$, future layers 2 to 6$)$, subplate $(S P)$, intermediate zone $(I Z$, future white matter), and ventricular zone ( $V Z$, zone of proliferating cells and future ependymal layer).

A comparison of the distribution of labeled cells in the darkfield autoradiograph with the adjacent cresyl violet-stained section shows that the labeled cells are present in both the marginal zone and in a zone located at the border between the cortical plate and the intermediate zone. Within this border zone, Figure 7 shows that labeled cells are located both at the base of the cortical plate and just below in a fibrous zone that constitutes the superficial part of the intermediate zone. Previous morphological (Kostovic and Molliver, 1974) and autoradiographic birth dating (Kostovic and Rakic, 


\section{$\mathrm{E} 26-\mathrm{E} 40$}
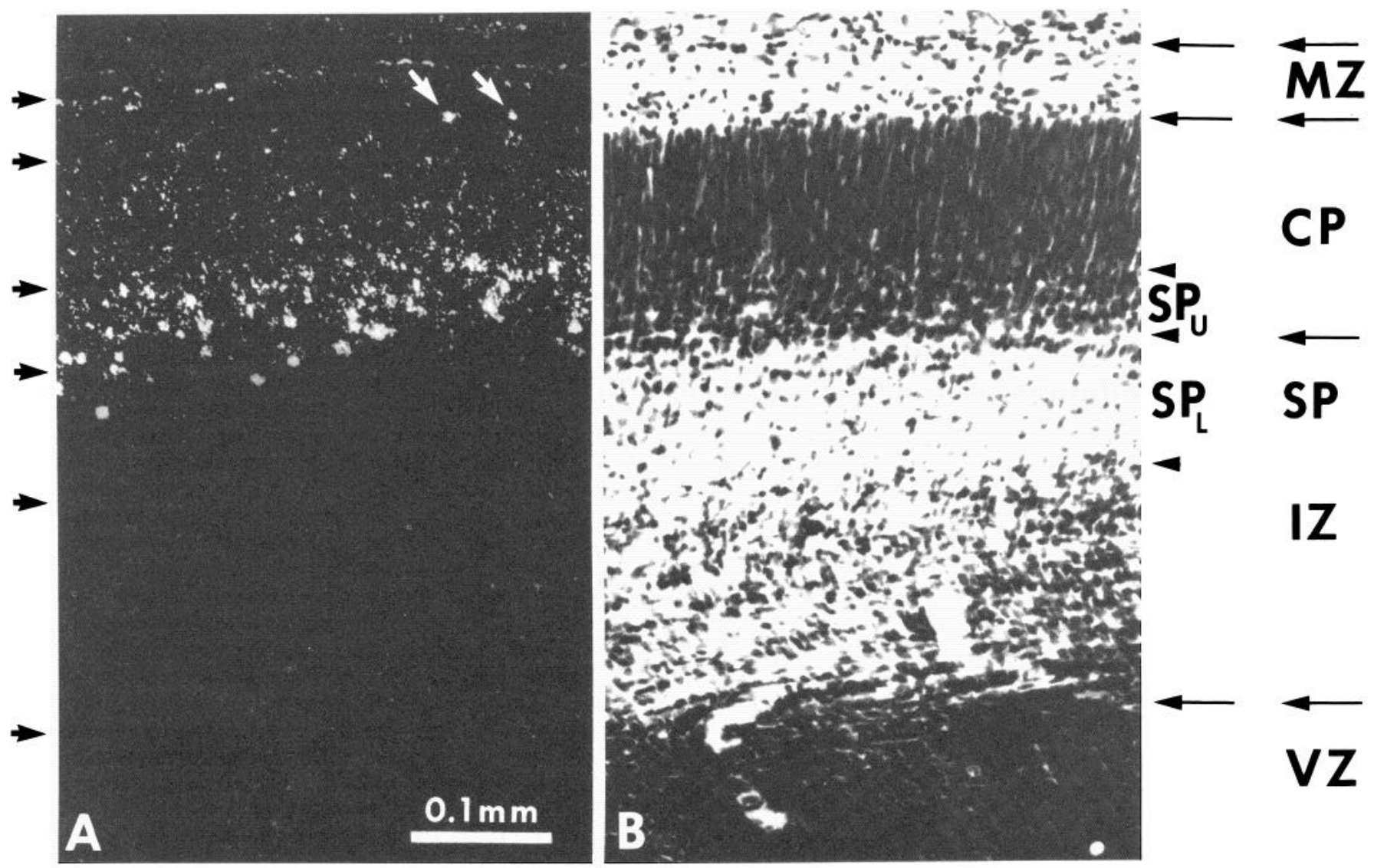

Figure 7. Distribution of labeled cells at $\mathrm{E} 40$ resulting from a $\left[{ }^{3} \mathrm{H}\right]$ thymidine injection on E26. $A$, the darkfield autoradiograph shows that the heavily labeled cells are situated in two tiers flanking the cortical plate $(C P)$ : one near the pial surface (the marginal zone $(M Z)$ or future layer 1 ; arrows indicate two heavily labeled cells), and the other (SPu) below the radially aligned cells of the cortical plate. $B$ is an adjacent cresyl violet-stained section illustrating the histological appearance of the presumptive visual cortex. The subdivisions listed under column 2 correspond to the nomenclature of the Boulder Committee (1970) modified by Rakic (1982), and those under column 1 correspond to the nomenclature proposed here for reasons discussed in the text. Note that, in column 1 , the subplate zone has been expanded to include an upper $\left(S P_{U}\right)$ and a lower $\left(S P_{L}\right)$ portion on the basis of histology and autoradiogrpahy. $I Z$, intermediate zone; SP, subplate; $V Z$, ventricular zone.

1980) studies have shown that, during development, this fibrous part of the intermediate zone in primates contains a similar population of early generated, transient cells ("interstitial neurons"). On this basis, and also because this portion of the intermediate zone was found to contain many synapses, Kostovic and co-workers identified this particular region as a distinct subdivision of the intermediate zone which they called the subplate. The results of Figure 7 demonstrate that, in the cat, as in the monkey, a similar subplate zone (Fig. 7, SP) can be identified.

Without our autoradiographic results, we would have been content to accept the borders of the subplate as described above. However, a simple inspection of Figure 7 shows that a significant fraction of the early generated cells are also located immediately above the subplate in a zone of densely packed cells that might classically be identified as the base of the cortical plate (Boulder Committee, 1970; Rakic, 1982). For the reasons described immediately below, we think it very unlikely that this zone is actually part of the cortical plate. Rather, we propose that this zone is an extension of the subplate. Accordingly, this zone of labeled cells is designated here as the upper portion of the subplate and labeled $S P_{U}$ in ensuing figures, and in Figures 4 and 6 , while the lower portion is labeled $S P_{L}$.

The principal reason we consider this upper zone to belong to the subplate is that a significant proportion of the earliest generated cells resides in this zone throughout prenatal life. This can be demonstrated by injecting a series of animals with $\left[{ }^{3} \mathrm{H}\right]$ thymidine at particular times between E24 and E30 and examining the autoradiographic labeling pattern at any convenient fetal age so long as the cortical plate and intermediate zone are distinct, such as E40. The results of such a set of experiments are shown in the histograms of Figure 8. Each histogram plots the distribution of heavily labeled cells with relative depth within the developing telencephalon as described under "Materials and Methods" (see Fig. 1). Injections at E24, E26, E28, and E30 labeled many cells within the densely packed zone at the base of the cortical plate, designated as $S P_{U}$. In addition, the injections at E24 and E26 also labeled cells within the lower half of the subplate $\left(S P_{L}\right)$. In view of the fact that injections given between E24 and E30 labeled many cells at the base of the cortical plate $\left(S P_{U}\right)$ at fetal ages (E40) but few if any cells in layer 6 of the adult (Luskin and Shatz, 1982; M. B. Luskin and C. J. Shatz, manuscript in preparation), we conclude that this zone, like the lower half of the subplate, is also a transient one and propose that it indeed constitutes a part of the subplate.

When the subplate population is considered as a whole $\left(S P_{L}\right.$ and $S P_{U}$ ), a spatiotemporal gradient of genesis becomes evident. This is also illustrated in Figure 8. For each histogram in Figure 8, an arrow indicates the median value for the entire distribution. $\left[{ }^{3} \mathrm{H}\right]$ Thymidine labeling at progressively older ages shifts the median to progressively more superficial levels within the subplate. This observation indicates that the subplate is formed between E24 and E30 

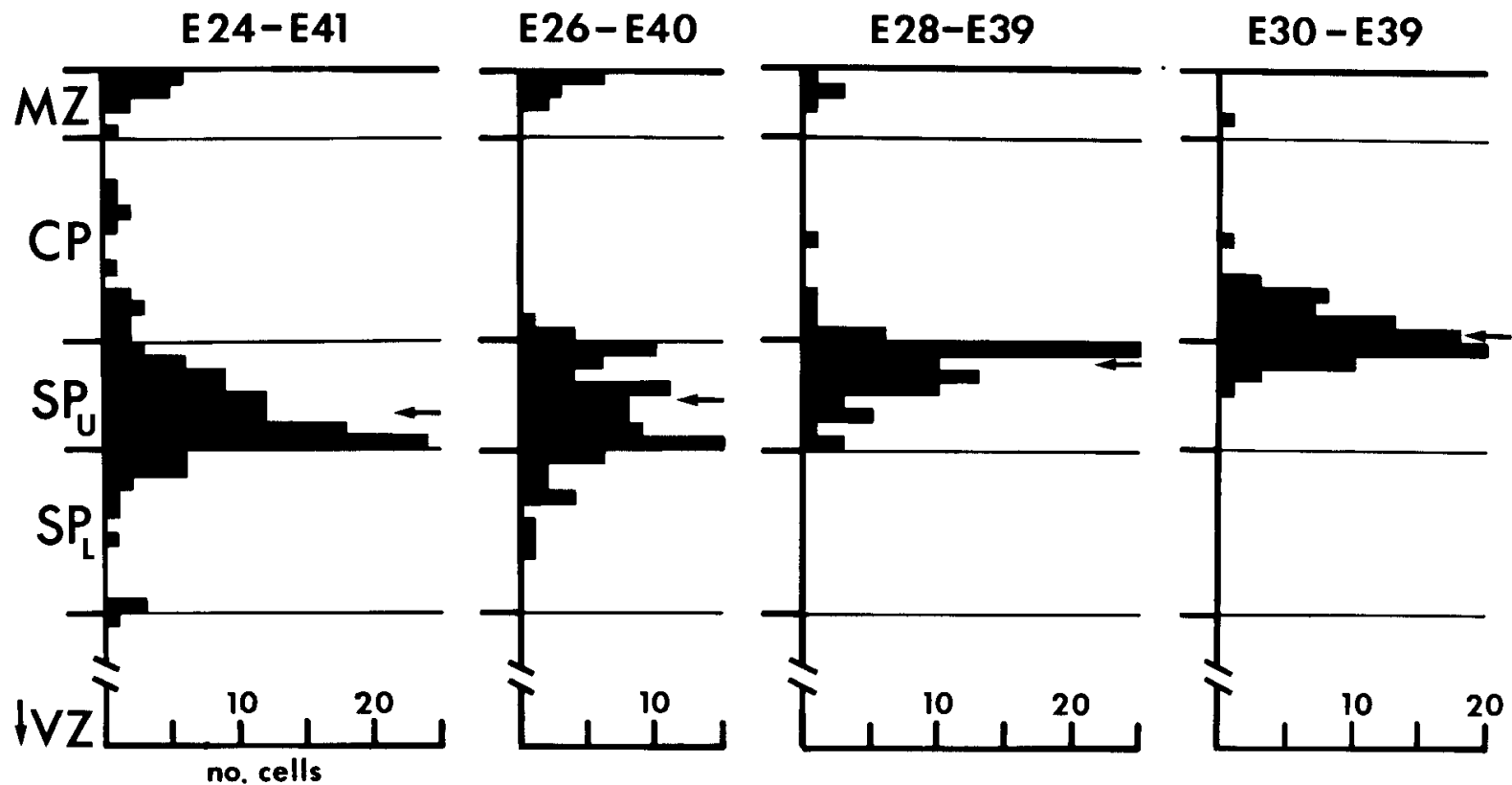

Figure 8. Distribution of labeled cells with depth in the presumptive visual cortex at about $E 40$ following $\left[^{3} H\right]$ thymidine injections at a range of earlier embryonic ages. Each histogram was constructed according to the procedure described under "Materials and Methods" and illustrated in Figure 1. Three sections were used to compile the E24 histogram, six for the E26 case, two for the E28 case, and one for the E30 case in order to obtain comparable numbers of heavily labeled cells. Collectively, the histograms show that the earliest generated cells reside primarily in the upper portion of the subplate $\left(S P_{u}\right)$. Injections given between E24 and E30 also label cells of the marginal zone (MZ). The arrow in each histogram indicates the median value of the entire distribution, which shifts to progressively more superficial levels after injections at succesive older ages. Note that the E30 injection labels many cells in the cortical plate $(C P)$ and correspondingly fewer in the upper portion of the subplate and the marginal zone. $S P_{L}$, lower portion of the subplate; $V Z$, ventricular zone.
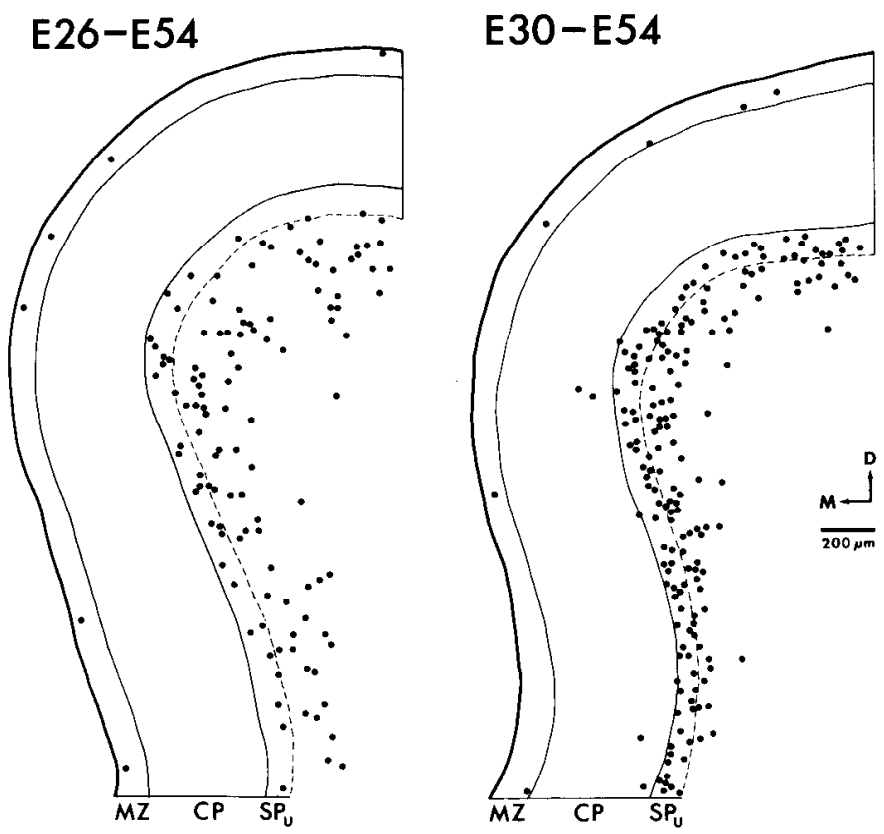

Figure 9. Camera lucida drawings of representative autoradiographs to show the distribution of labeled cells in the presumptive visual cortex at E54 resulting from $\left[{ }^{3} \mathrm{H}\right]$ thymidine injections on E26 (left) or E30 (right). Heavily labeled cells (black dots) in both cases underly the cortical plate $(C P)$, with a substantial portion (particularly after the E30 injection) located in the upper portion of the subplate $\left(S P_{U}\right)$. Labeled cells are present in the marginal zone $(M Z)$ as well. Dorsal $(D)$ is up and medial $(M)$ is to the left in this coronal section taken through the midportion of the lateral geniculate nucleus.

in an inside-first outside-last fashion, just like the overlying cortical plate during the ensuing period between E31 and E57.

If the entire subplate population constitutes a distinct embryological layer within the developing telencephalon, then it should remain fixed in position below the cortical plate until it disappears. This can be directly demonstrated both autoradiographically and histologically. For example, any time the fetal telencephalon was examined following a $\left[{ }^{3} \mathrm{H}\right]$ thymidine injection made between E24 and E30, the vast majority of labeled cells were always located at the border of the cortical plate and the intermediate zone. We have already shown that this is the case at E40 (Figs. 7 and 8), a time when the cortical plate is relatively thin. Figure 9 shows that, even 2 weeks later, at E54, the early generated cells still sit in this border region, indicating that a subplate zone is present at later ages as well.

It is also noteworthy that, prior to birth, the autoradiographic distribution of early generated cells always coincides with a histologically identifiable zone. As can be seen from a comparison of Figure 7. $A$ and $B$, at $E 40$ this zone consists of the upper $\left(S P_{U}\right)$ and lower $\left(S P_{L}\right)$ subdivisions of the subplate. Careful inspection of the cresyl violet-stained section reveals that the upper subdivision can be distinguished from the overlying cortical plate histologically: the cells of the cortical plate are tightly packed and radially aligned, whereas those of the subplate appear more loosely packed and rounder in shape.

The progressive changes in this histological organization with age are shown in Figure 10, a series of cresyl violet-stained sections through the occipital cortex at E41, E57, P1, and adult. At each age, the autoradiographic labeling pattern following an early $\left[{ }^{3} \mathrm{H}\right]$ thymidine injection (E24 to E30) was used to determine the location of the upper border of the subplate. As can be seen in Figure 10, at E41, E57, and P1, a histologically identifiable zone lying immediately below the cortical plate is delimited. The division between the upper and lower parts of the subplate can also be located histologically at the top of the intermediate zone (Fig. 10, IZ) or white matter (Fig. $10, W M$ ) at these ages, where there is a further decrease in cell density. In contrast, by P67 the subplate no longer exists as a histologically identifiable zone; all that remains is the occasional spindle-shaped cell embedded in the white matter below layer 6 . Thus, taken together, these autoradiographic and histological results indicate that the early generated cells of the subplate indeed con- 

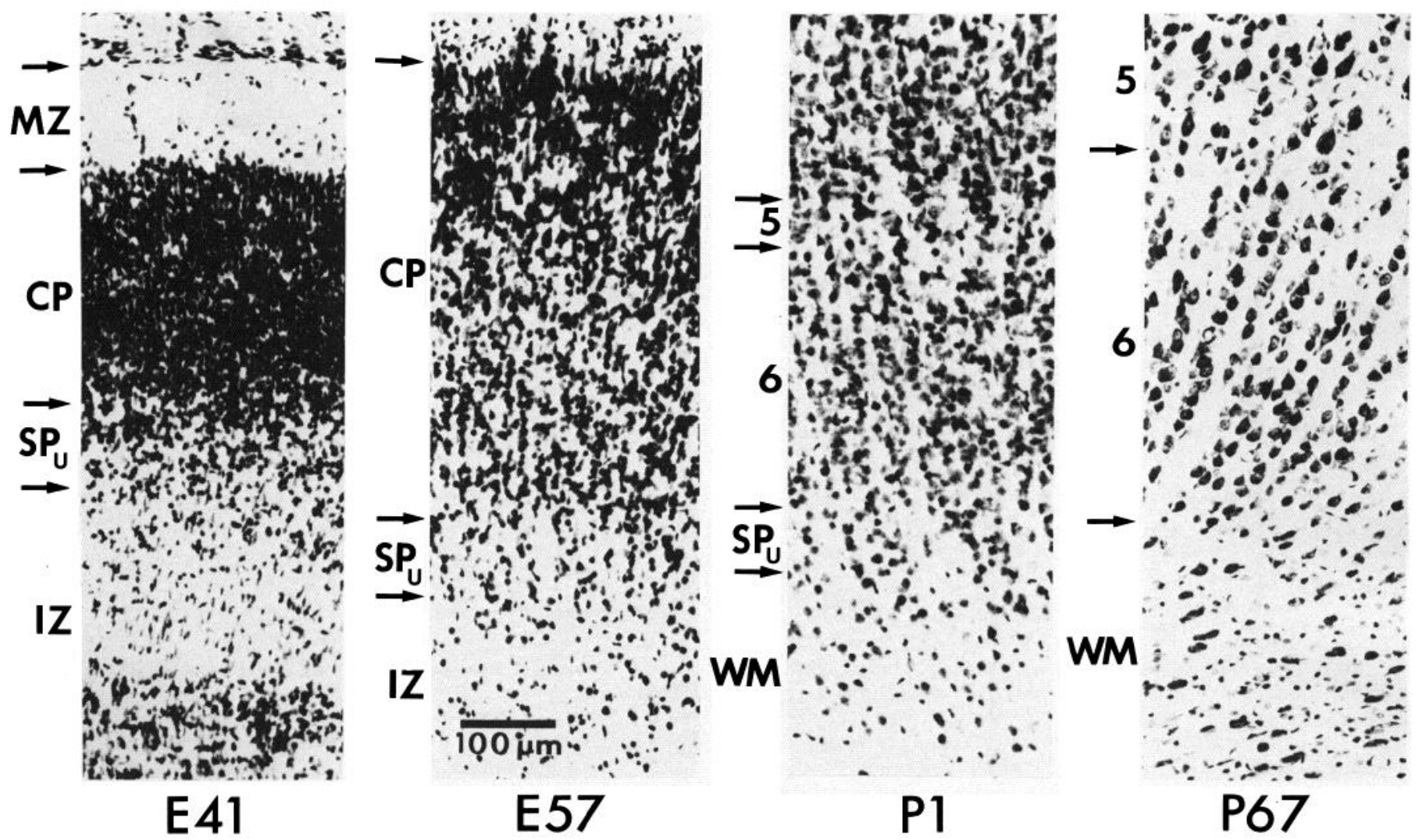

Figure 10. A series of cresyl violet-stained coronal sections through the presumptive visual cortex at E41, E57, P1, and in the adult to illustrate the progressive changes in the histological organization of the subplate. For each panel, the autoradiographic labeling pattern in an adjacent section resulting from an early $\left[{ }^{3} \mathrm{H}\right]$ thymidine injection (E24 to E30) was used to determine the upper border of the upper subplate (SPu). Note that the upper subplate is a histologically distinct zone located between the more densely packed cortical plate $(C P)(E 41, E 57$, and $P 1)$ above, and the more loosely packed intermediate zone (IZ) (E41 and E57) or white matter (WM) (P1) below. By P67 the upper subplate no longer exists; only occasional spindle-shaped cells remain in the white matter below layer 6. MZ, marginal zone. The 100- $\mu \mathrm{m}$ calibration bar applies to each panel.

stitute a temporary embryonic layer which remains stationary despite the fact that later generated cells en route to the developing cortical plate must migrate through it.

Cogeneration of cells of the subplate and marginal zones. So far, we have presented evidence based on $\left[{ }^{3} \mathrm{H}\right]$ thymidine autoradiography to suggest that the subplate exists as a temporary embryonic zone. In the course of the experiments described above, however, another discrete population of cells situated in future layer 1 was routinely labeled following $\left[{ }^{3} \mathrm{H}\right]$ thymidine injections between E24 and E30. For example, labeled cells were seen in the marginal zone at E40 (Fig. 7), E54 (Fig. 9), and at birth in layer 1 (Figs. 4 and 5) following early $\left[{ }^{3} \mathrm{H}\right]$ thymidine injections. Furthermore, like the cells of the subplate, the early generated marginal zone cells are also greatly diminshed in number by adulthood as shown in Figure 3 (E28 to P78). This pattern of development is virtually identical to that of the Cajal-Retzius cells studied in many other species (Ramón y Cajal, 1890, 1911; Sas and Sanides, 1970; Edmunds and Parnavelas, 1982) and indicates that these cells constitute the population of Cajal-Retzius cells in the cat's telencephalon.

In the course of analyzing the genesis of the subplate cells, we produced material useful in determining accurately the time course of genesis of these marginal zone cells as well. Thus, $\left[{ }^{3} \mathrm{H}\right]$ thymidine injections made any time between E24 and E30 labeled not only the subplate cells, but also those of the marginal zone. This point is illustrated in the histograms of Figure 8, which show further that E30 marks not only the conclusion of the period of subplate genesis, but also that for cells of the marginal zone. Similarly, injections made on E17, E19, E20, and E21 failed to label either population. These results indicate that the cells of both the marginal zone and the subplate of the occipital pole are generated concurrently during the period between E24 and E30.
Not only are these two populations of cells cogenerated, but they also both achieve a distinctly differentiated appearance during fet:al life. This point is illustrated in Figure 11, in which the histological appearance at E54 of cells labeled at E26 is shown in cresyl violetcounterstained autoradiographs. At this fetal age, the labeled cells in both the marginal zone (Fig. 11A) and subplate (Fig. 11B) are significantly more differentiated than their nearby neighbors within the cortical plate or those presumably migrating through the intermediate zone. The labeled cells are uniformly larger and rounder than the smaller, radially aligned cells of cortical plate and intermediate zone. Their differentiated state is further signified by the presence of faintly stained processes emanating from cell somas.

Since these two populations are cegenerated, it occurred to us that they might exist initially as a single homogeneous sheet of cells that is subsequently split apart by the later generated cells forming the cortical plate. If so, then there should be a time early in development, prior to the formation of the cortical plate, when only a single sheet of labeled cells is produced following a $\left[{ }^{3} \mathrm{H}\right]$ thymidine injection given before E30. To test this hypothesis, we injected $\left[{ }^{3} \mathrm{H}\right]$ thymidine at E24 and examined the labeling pattern present at E30, a time when the first cells of the occipital cortical plate are just undergoing their final round of DNA synthesis and therefore have not yet begun their migration out of the ventricular zone. The injection was made at E24 in order to label exclusively the cells of the subplate and marginal zones and give them plenty of time to migrate away from the ventricular zone.

The results of this experiment are shown in Figure 12. The histological appearance of the telencephalon is shown in the cresyl violet-stained horizontal section of Figure 12A. A clear developmental gradient is evident here: the more lateral and anterior regions (to the 

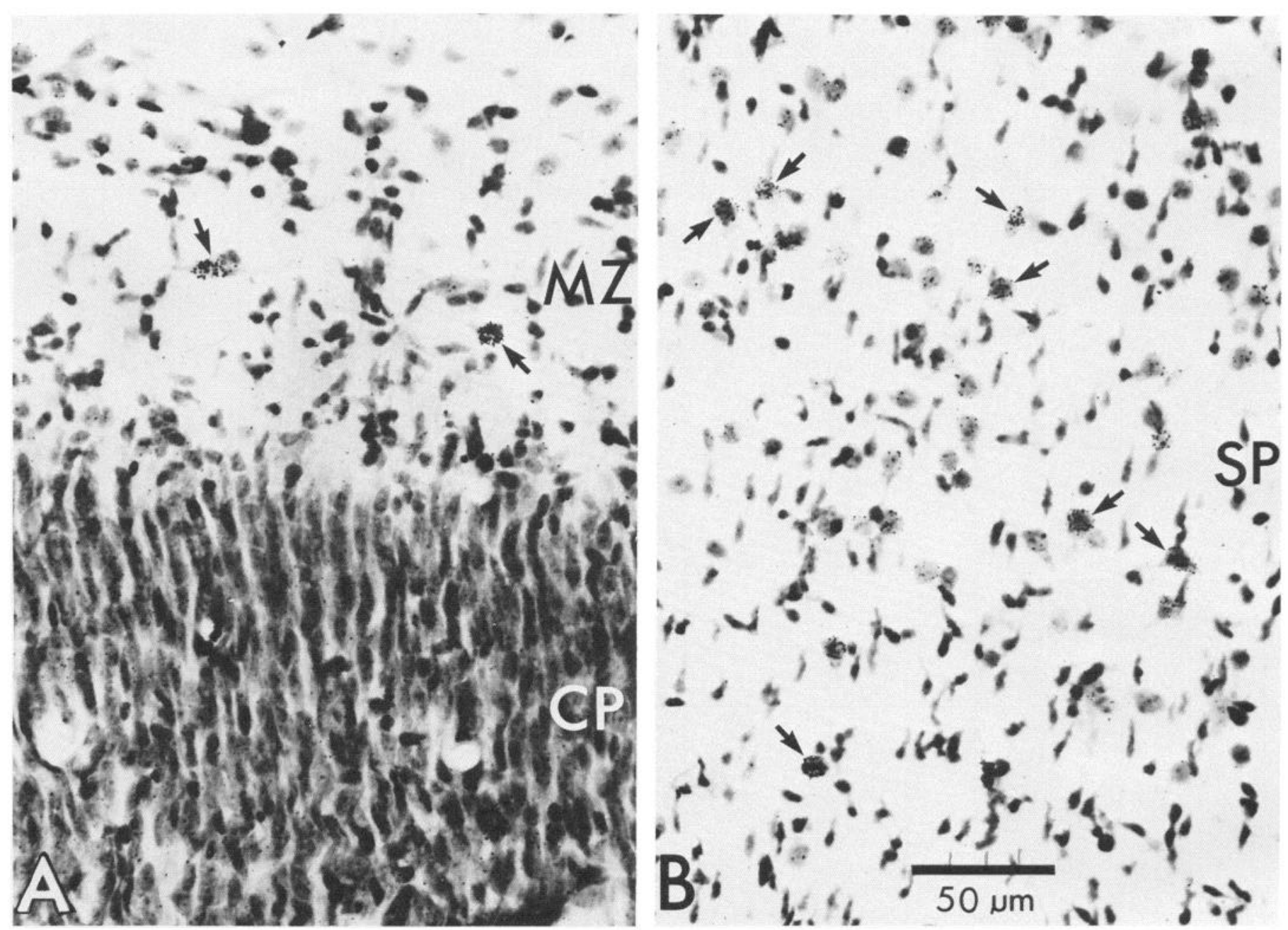

Figure 11. High power brightfield autoradiographs counterstained with cresyl violet of the marginal zone $(M Z)(A)$ and subplate $(S P)(B)$ at E54 following a $\left[{ }^{3} \mathrm{H}\right]$ thymidine injection on E26 to illustrate the histological appearance of the early generated cells of the visual cortex. Note the large size of labeled cells in both the marginal zone and the subplate (arrows) and the faintly stained processes emanating from some of the cells. The 50- $\mu \mathrm{m}$ calibration bar applies to both $A$ and $B$. In $A$ and $B$, superficial is up.

left) are further developed than the occipital pole (right), as demonstrated by the progressive condensation of cells forming the incipient cortical plate within more anterior regions. As expected in view of the absence of a cortical plate in the occipital pole, labeled cells are distributed throughout the marginal and intermediate zones as a single homogeneous population. This is illustrated in the brightfield autoradiograph of Figure $12 \mathrm{C}$. In contrast, where the cortical plate has already begun to form in regions outside the occipital pole (Fig. 12B), labeled cells are distributed in two tiers above and below the cortical plate: in the marginal zone and in both the upper and lower regions of the subplate. These results indicate that the subplate and marginal zone cells of the occipital pole do indeed begin as a contiguous population.

To dramatize the fact that this population is later split apart by cells of the cortical plate, a final set of experiments is illustrated in Figure 13. Here, we compare at E57 the distribution resulting from an injection designed to label cells of the subplate and marginal zones on the one hand with an injection designed to label cells of the cortical plate on the other. As always, an injection at E24 labeled cells above and below the cortial plate (Fig. 13, E24 to E57), whereas an injection at E37 exclusively labeled cells within the intervening cortical plate. From other expeirments, we know that these cells belong to layers 4 to 6 in the adult primary visual cortex (Luskin and Shatz, 1982; M. B. Luskin and C. J. Shatz, manuscript in preparation). In view of the fact that any $\left[{ }^{3} \mathrm{H}\right]$ thymidine injection made after E30 routinely labels only cells of the cortical plate in the embryo and their mature counterparts within the cellular layers of the cortex in the adult, we conclude that the earlier cogenerated subplate and marginal zone cells are indeed split apart by the later generated cells that give rise to the mature visual cortex.

\section{Discussion}

This study has shown that a transient population of cells participates in the formation of the adult cat's visual cortex. By means of $\left[{ }^{3} \mathrm{H}\right]$ thymidine autoradiography, we have found that this population is the earliest generated of the telencephalon, with the majority of cells produced during the 1 -week period just preceding the genesis of the cells destined to comprise the cortical layers in the adult. During fetal development, these early generated cells initially reside within a single stratum that is subsequently split into two embryonic zones that flank the developing cortical plate: above in the marginal zone, and below in the subplate zone. At birth, they can still be found in layer 1 and the white matter, but by 2 months postnatal, very few persist as judged by retention of the $\left[{ }^{3} \mathrm{H}\right]$ thymidine label. This sequence of development is illustrated in Figure 14.

By analogy with studies in other species, we believe that the early generated cells studied here correspond at least in part to the CajalRetzius cells of the marginal zone (Ramón y Cajal, 1890, 1911; Bradford et al., 1977), on the one hand, and to the interstitial cells of the subplate (Kostovic and Rakic, 1980), on the other. For 


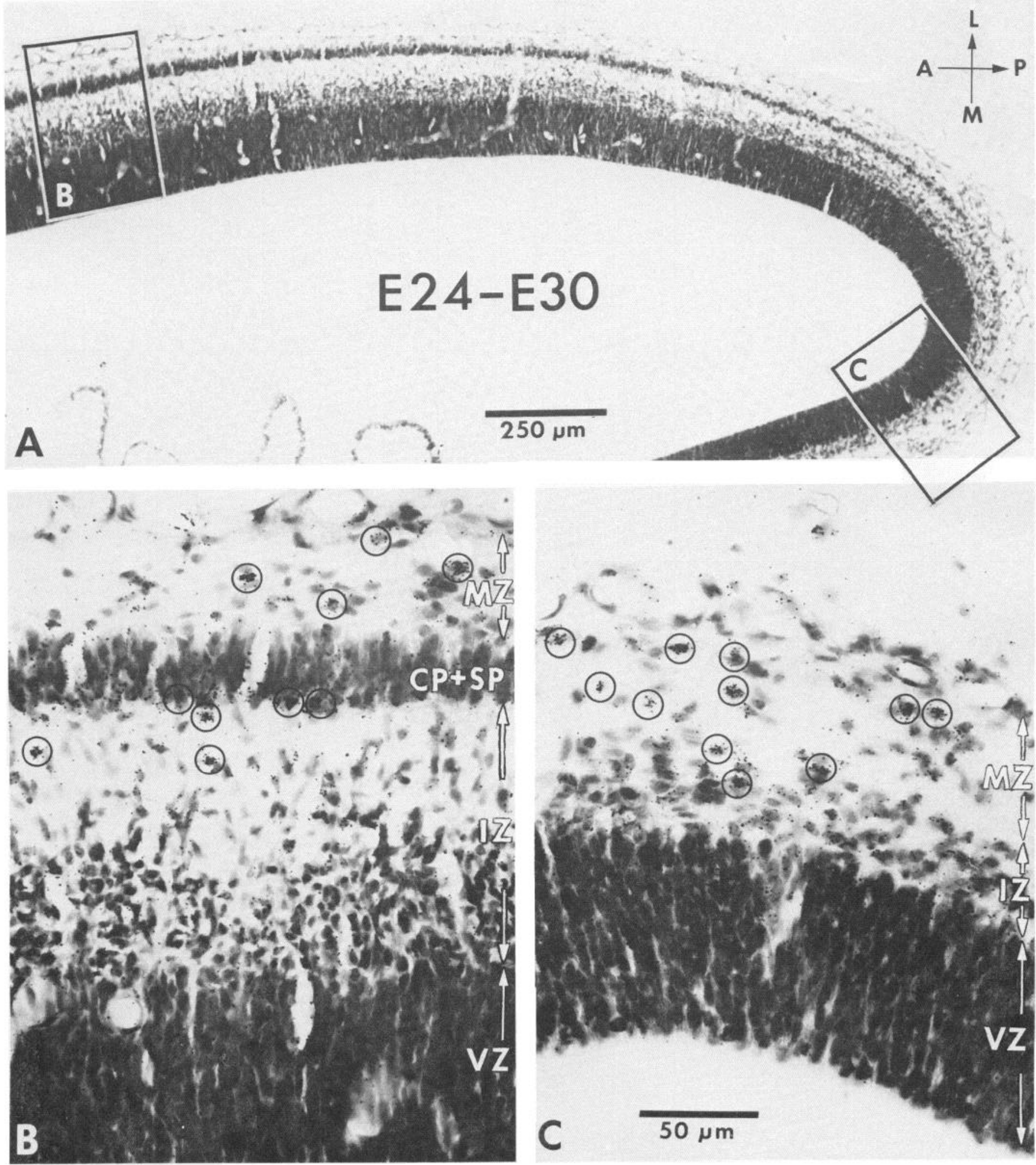

Figure 12. Differential distribution of heavily labeled cells depending on location at $\mathrm{E} 30$ following a $\left[{ }^{3} \mathrm{H}\right]$ thymidine injection at $\mathrm{E} 24$. A, Low power view of a cresyl violet-stained horizontal section through the telencephalon at E30 to illustrate the gradient in development of the cortical plate. Note the increasing condensation of cells forming the incipient cortical plate $(C P)$ from the posterior pole (far right) where the cortical plate does not exist, to more anterior and lateral regions (far left). B and $C$. High power brightfield autoradiogaphs of the areas enclosed by boxes in $A$ to illustrate the distribution of labeled cells (circled). C, At the occipital pole, shows that labeled cells occur throughout the marginal zone (MZ) and intermediate zone (IZ) as a homogeneous population of cells. In contrast, $B$ shows that the labeled cells are located mostly above and below the cortical plate. The calibration bar in $C$ also applies to B. 


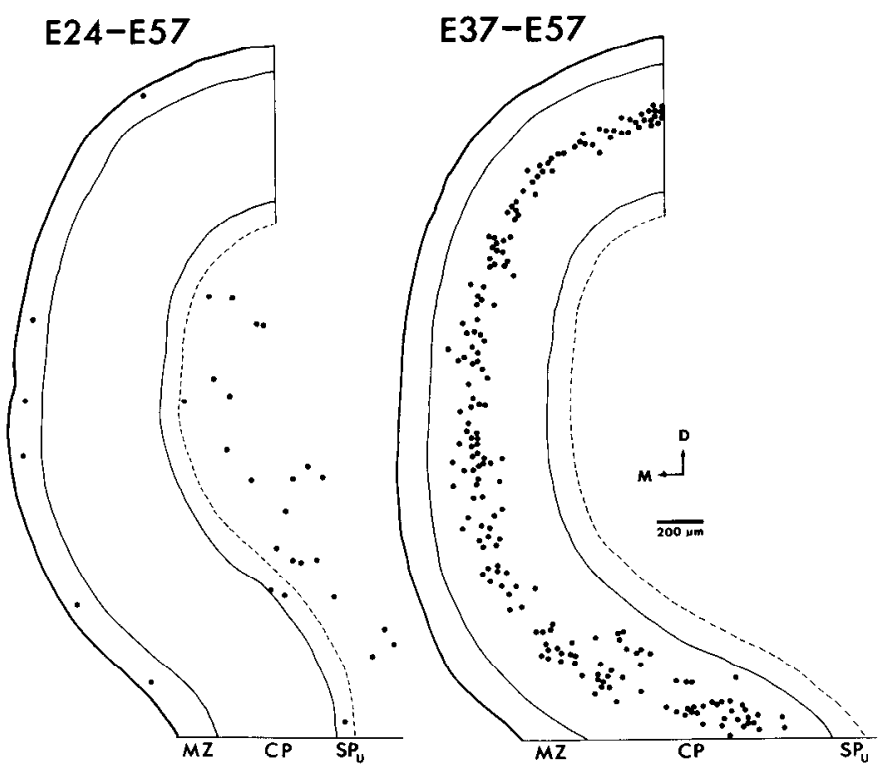

Figure 13. Camera lucida drawings of representative autoradiographs to show the distribution of heavily labeled cells (black dots) in the presumptive visual cortex at E57 following $\left[{ }^{3} \mathrm{H}\right]$ thymidine injections at E24 (left) or E37 (right). Together they illustrate that the later generated cells of the cortical plate $(C P)$ are inserted between the early generated cells of the marginal zone $(M Z)$ and the subplate $(S P)$. Dorsal $(D)$ is up and medial $(M)$ is to the left in these drawings of coronal sections taken through the midportion of the lateral geniculate nucleus.

example, $\left[{ }^{3} \mathrm{H}\right]$ thymidine labeling studies in rodents have shown that, as in the cat, some of the first-generated cells of the telencephalon reside in the marginal zone during development, yet these cannot be found in layer 1 by adulthood (Raedler and Raedler, 1978; Shoukimas and Hinds, 1978; Caviness, 1982). In a combined electron microscopic-autoradiographic study, Parnavelas and Edmunds (1983) showed further that these early generated cells indeed correspond morphologically to the class of Cajal-Retzius cells known to be present in layer 1 in large numbers at birth (Rickmann et al., 1977; Konig et al., 1981; Edmunds and Parnavelas, 1982) but rarely found in layer 1 of the adult. From these observations, we believe that the population of early generated cells of the marginal zone studied here autoradiographically in the cat correspond at least in part to the Cajal-Retzius cells which are also found in Golgi studies of the cat's cerebral cortex (Sas and Sanides, 1970; Marin-Padilla, 1971, 1972).

Less information is available about the cellular composition and time of origin of the subplate zone of the telencephalon. In primates, Kostovic and Rakic (1980) have shown that among the earliest generated cells of the telencephalon are a transient class belonging to the subplate referred to as the "interstitial cells;" however, they found these to be generated concomitantly with cells of cortical layer 6 . Our own autoradiographic results suggest that, although this is indeed the case in the cat as well, the majority of cells belonging to the subplate are actually generated as much as 1 week earlier than those of cortical layer 6 (see Fig. 8 and M. B. Luskin and C. J. Shatz, manuscript in preparation), and we would predict that this is the case in primates as well.

Our results also show that, in the fetus, the class of early generated transient cells occupies a more extensive zone than that described as the subplate by Kostovic and Rakic (1980) in the primate. Based on a comparison of the autoradiographic labeling patterns in fetal and adult cats, we have extended the border of the subplate upwards to include a region classically considered to belong to the base of the cortical plate (future layer 6 ). We have done so because, in the adult, early generated cells are rarely found in cortical layer 6 , suggesting that in the fetus, the early generated cells situated at the base of the cortical plate do not persist into adulthood and therefore
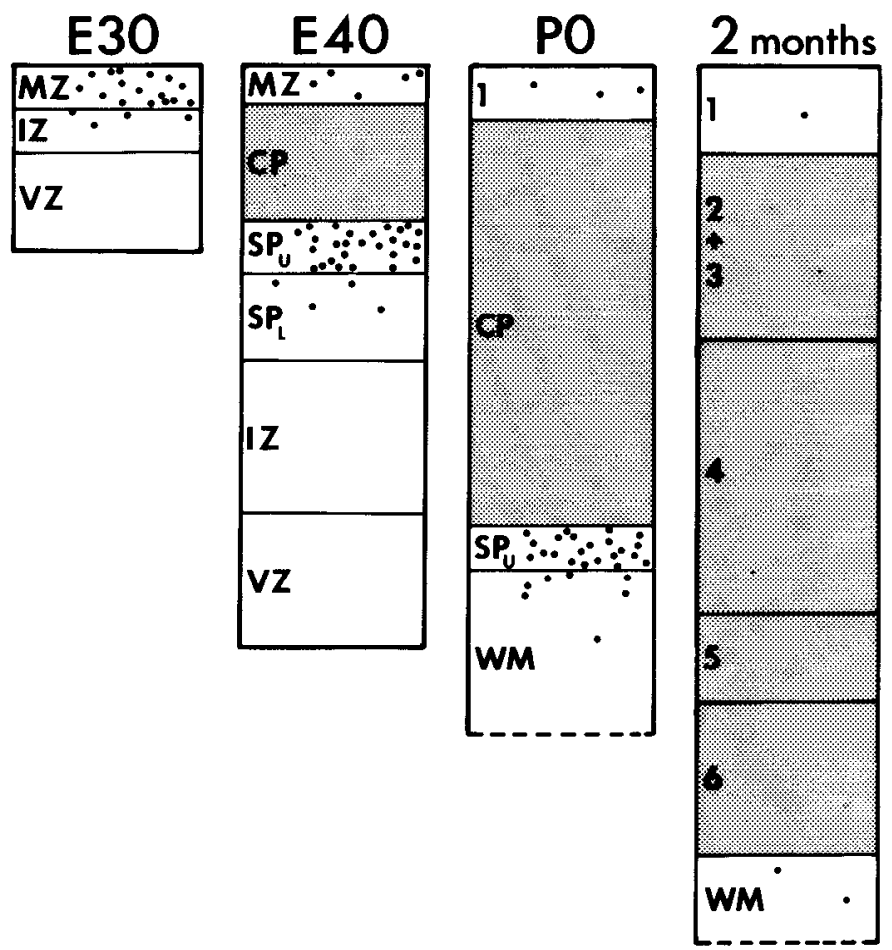

Figure 14. Summary diagram of the sequence of development and disappearance of the earliest generated cells (represented as black dots) of the visual cortex. After these cells migrate away from the ventricular zone $(V Z)$, they initally reside in the marginal $(M Z)$ and intermediate $(I Z)$ zones as a contiguous population of cells $(E 30)$. By $E 40$ this population has been split apart by the insertion of the later generated cells of the cortical plate $(C P)$. As a consequence, some of the early generated cells reside in the marginal zone, whereas others are situated in the upper and lower portions of the subplate $\left(S P_{U}\right.$ and $\left.S P_{L}\right)$, a transient embryonic layer. At birth $(P O)$, substantial numbers of the early generated cells are still present in the subplate, white matter (WM), and layer 1. However, sometime between birth and 2 months postnatal, most of the early generated cells disappear.

constitute a transient embryonic zone that should be considered part of the conventionally recognized subplate below. In fact, it may even be that the first condensation of cells to form the cortical plate actually represents the formation of the condensed subplate zone that we have designated as the upper half of the subplate $\left(S P_{U}\right)$ in our study, and the formation of the portion of the cortical plate that gives rise to the cells of adult layer 6 occurs shortly thereafter.

The question arises whether the organization of the subplate as described above is unique to the cat, or whether it is a general feature of mammalian cerebral cortical development. Although there have been several autoradiographic studies of rodent cerebral cortical development, there is disagreement about the time of origin and embryonic location of future cortical layer 6 (Raedler and Raedler, 1978; Shoukimas and Hinds, 1978; Caviness, 1982). It may be that the disagreement stems from difficulties in identifying future cortical layer 6 and the upper subplate. In our own case, without the extensive collection of $\left[{ }^{3} \mathrm{H}\right]$ thymidine material from both fetal and adult cats, it would have been impossible to draw conclusions concerning the location of the subplate and future cortical layer 6 during development. However, given our results, we would expect that the pattern of cortical development in rodent and primate brain would be rather similar to that described here.

Another issue concerns the exact relationship between the genesis of cells belonging to the marginal zone and subplate. Although there is general agreement that in every species studied the two sets of cells are among the earliest to be generated, here we have demonstrated directly that not only are the two sets of cells cogenerated, but also that they exist initially as a contiguous population that is later split apart by the accretion of cells of the cortical plate. 
This may be the case in rodents as well, since, in the rat, Raedler and Raedler (1978) have shown that injection of $\left[{ }^{3} \mathrm{H}\right]$ thymidine on $E 12$ results initially in one labeled population which is later split into two parts in a fashion analogous to that occuring in the cat. However, they identify upper and lower parts as belonging to the marginal zone and future cortical layer 6 , respectively. We suggest, however, that it might be more appropriate to consider the lower part as belonging to the subplate rather than layer 6 .

The finding here that the cells of the marginal zone and subplate are cogenerated, and that both sets disappear after birth, makes it likely that whatever role they play during development is, at least in part, a common one. In the embryonic brain of many species, cells situated in both the marginal zone and what we call the subplate zones are morphologically distinct from the less mature cells of the cortical plate. Golgi studies show that many of these cells have large somas and extensive processes (Ramón y Cajal, 1911; Aström, 1967; Sas and Sanides, 1970; Marin-Padilla, 1971, 1972; Bradford et al., 1977; Rickmann et al., 1977), and electron microscopic studies demonstrate that at least some of these cells have the ultrastructural appearance of neurons and receive synapses (Konig et al., 1975; Rickmann et al., 1977; Kostovic and Rakic, 1980; Edmunds and Parnavelas, 1982). Indeed, both populations of cells are commonly thought of as neurons, and this is further supported by Konig and Schachner's (1981) finding that the Cajal-Retzius cells have antigenic determinants recognized by a neuron-specific antibody and do not contain glial fibrillary acidic protein. Our own preliminary observations also indicate that some of the marginal zone and subplate cells are immunohistochemically stained by an antibody to the neurotransmitter-synthesizing enzyme, glutamic acid decarboxylase (M. B. Luskin, S. L. Shotwell, and C. J. Shatz, manuscript in preparation).

These observations have led to the conclusion that both marginal zone and subplate cells may act as temporary targets for ascending afferent systems to the cerebral cortex (Marin-Padilla, 1978; Kostovic and Rakic, 1980). Although this is a very plausible suggestion, the finding here, that the two sets of cells are cogenerated, suggests an additional role: these cells may provide a cellular framework for the construction and development of the cortical plate itself. In this context, it is interesting to note that Golgi studies in the cat show that both sets of cells are interconnected with each other by processes spanning the thickness of the cortical plate during fetal life (Marin-Padilla, 1971, 1972; Marin-Padilla and Marin-Padilla, 1982): Bascd on the radiographic results described here, we consider it highly likely that layer 7 of Marin-Padilla corresponds to the subplate zone)

Inspection of our autoradiographic material indicates that the role played by both sets of cells, whatever it may be, is limited to fetal and early postnatal life. By 2 months postnatal, nearly all of the cells labeled by an injection of $\left[{ }^{3} \mathrm{H}\right]$ thymidine prior to E30 have disappeared. The fate of these cells, particularly the Cajal-Retzius cells, has been the subject of much speculation, but the best evidence based on electron microscope $\left[{ }^{3} \mathrm{H}\right]$ thymidine autoradiography suggests that, in the rat, the majority die, while the remaining few persist in the adult as nonpyramidal neurons of layer 1 (Parnavelas and Edmunds, 1983). We propose here a similar fate for the cells of the subplate: the majority of the early generated cells are eliminated by cell death, and those that do persist into adulthood are principally the fusiform cells of the white matter that we see $\left[{ }^{3} \mathrm{H}\right]$ thymidine labeled in our material (Fig. 2). This suggestion is consistent with the observation that enormous numbers of macrophages are temporarily present within the white matter of the cat's visual cortex between 1 and 4 weeks postnatal (Innocenti et al., 1983) and could therefore function to remove the cellular debris from the dying early generated cells.

We consider cell death the most likely mechanism responsible for the reduction in cell number rather than dilution due to growth of the brain (Rickmann et al., 1977) because comparable numbers of cells are generated for the subplate as for the deep cortical layers, and both are present in comparable numbers at birth. This observation makes it difficult to argue that differential growth of the brain would dilute out one population (the subplate) without affecting the adjacent population (cortical layers 5 and 6) similarly. Another possibility is that subplate cells undergo many rounds of cell division after birth, thereby diluting out the original $\left[{ }^{3} \mathrm{H}\right]$ thymidine label. Preliminary experiments suggest that this is not likely to be the case, since daily administration of $\left[{ }^{3} \mathrm{H}\right]$ thymidine between $\mathrm{P} 10$ and $\mathrm{P} 14$ does not selectively label cells in the white matter-rather, glial cells everywhere are labeled.

If cell death is indeed responsible for eliminating both the marginal zone and the subplate cells, then this sequence of development would constitute one of the few known cases in the mammalian CNS in which the cellular components that participate in embryonic development die rather than acquire a role in the adult CNS. Other examples of cells undergoing this variety of cell death include the Rohon-Beard cells of the amphibian spinal cord (Spitzer and Lamborghini, 1981), and the border cells of the primate spinal cord (Knyihar et al., 1978). Again, both of these cell types are present for a defined but limited period during embryonic development. This variety of cell death should be distinguished from the "naturally occurring cell death" (Hamburger and Oppenheim, 1982) that is involved in matching the size of a neuronal population with its target population. For example, during spinal cord development, motoneurons are initially overproduced (Hamburger, 1976), and the size of the remaining population is controlled by their target musculature (Hollyday and Hamburger, 1976). Similar considerations cannot account for the disappearance of the cells of the marginal zone and white matter in the cat's visual cortex. However, it is noteworthy that their disappearance by 2 monthis pustriatal occurs after all of the cells destined to belong to the cortical plate have completed their migrations and also after the major ascending afferent systems have invaded the cortex (Luskin and Shatz, 1984). Their disappearance in conjunction with these events may indicate that these cells play a unique role in the establishment of the cerebral cortex, and, once this role is complete, they are eliminated by cell death.

\section{References}

Aström, K. E. (1967) On the early development of the isocortex in fetal sheep. Prog. Brain Res. 26: 1-59.

Boulder Committee (1970) Embryonic vertebrate central nervous system: Revised terminology. Anat. Rec. 166: 257-261.

Bradford, R., J. G. Parnavelas, and A. R. Lieberman (1977) Neurons in layer 1 of the developing occipital cortex of the rat. J. Comp. Neurol. 176: 121132.

Caviness, V. S., Jr. (1982) Neocortical histogenesis in normal and reeler mice: A developmental study based upon ${ }^{3} \mathrm{H}$-thymidine autoradiography. Dev. Brain Res. 4: 293-302.

Cragg, B. G. (1972) The development of synapses in cat visual cortex. Invest. Ophthalmol. 11: 377-385.

Duckett, S., and A.G.E. Pearse (1968) The cells of Cajal-Retzius in the developing human brain. J. Anat. 102: 183-187.

Edmunds, S. M., and J. G. Parnavelas (1982) Retzius-Cajal cells: An ultrastructural study in the developing visual cortex of the rat. J. Neurocytol. 11: $427-446$

Hamburger, V. (1976) Cell death in the development of the lateral motor column of the chick embryo. J. Comp. Neurol. 160: 535-546.

Hamburger, V., and R. W. Oppenheim (1982) Naturally occurring neuronal death in vertebrates. Neurosci. Comment. 1: 39-55.

Hickey, T. L., and N. R. Cox (1979) Cell birth in the lateral geniculate nucleus of the cat: $\mathrm{A}^{3} \mathrm{H}$-thymidine study. Soc. Neurosci. Abstr. 5: 788.

Hickey, T. L., D. R. Whikehart, C. A. Jackson, P. F. Hitchcock, and J. D. Peduzzi (1983) Tritiated thymidine experiments in the cat: A description of techniques and experiments to define the time-course of radioactive thymidine availability. J. Neurosci. Methods 8: 139-147.

Hollyday, M., and V. Hamburger (1976) Reduction of naturally occurring motor neuron loss by enlargement of the periphery. J. Comp. Neurol. 170: 311-320.

Innocenti, G. M., S. Clarke, and H. Koppel (1983) Transitory macrophages in the white matter of the developing visual cortex. II. Development and relations with axonal pathways. Dev. Brain Res. 11: 39-53. 
Knyihar, E., B. Csillik, and P. Rakic (1978) Transient synapses in the embryonic primate spinal cord. Science 202: 1206-1209.

Konig. N. and M. Schachner (1981) Neuronal and glial cells in the superficial layers of early postnatal mouse neocortex: Immunofluorescence observations. Neurosci. Lett. 26: 227-231.

Konig, N., G. Roch, and R. Marty (1975) The onset of synaptogenesis in rat temporal cortex. Anat. Embryol. 148: 73-87.

Konig, N., J. -P. Hornung, and $H$. Van der Loos (1981) Identification of CajalRetzius cells in immature rodent cerebral cortex: A combined Golgi-EM study. Neurosci. Lett. 27: 225-229.

Kostovic, 1., and M. E. Molliver (1974) A new interpretation of the laminar development of cerebral cortex: Synaptogenesis in different layers of neopallium in the human fetus. Anat. Rec. 178: 395.

Kostovic, I., and P. Rakic (1980) Cytology and time of origin of interstitial neurons in the white matter in infant and adult human and monkey telencephalon. J. Neurocytol. 9: 219-242.

LeVay, S., M. P. Siryker, and C. J. Shatz (1978) Ocular dominance columns and their development in layer IV of the cat's visual cortex: A quantitative study. J. Comp. Neurol. 179: 223-244.

Levitt, P., and P. Rakic (1980) Immunoperoxidase localization of glial fibrillary acidic protein in radial glial cells and astrocytes of the developing rhesus monkey brain. J. Comp. Neurol. 193: 815-840.

Luskin, M. B., and C. J. Shatz (1982) Neurogenesis of the cat's primary visual cortex. Soc. Neurosci. Abstr. 8: 3.

Luskin, M. B., and C. J. Shatz (1983) Cogeneration of subplate and marginal zone cells in the cat's primary visual cortex. Soc. Neurosci. Abstr. 9: 910.

Luskin, M. B., and C. J. Shatz (1984) Spatio-temporal relations between the cells of layers 4 and 6 and their geniculocortical afferent input during development. Soc. Neurosci. Abstr. 10: 1079.

Marin-Padilla, M. (1971) Early prenatal ontogenesis of the cerebral cortex (neocortex) of the cat (Felis domestica). A Golgi study. I. The primordial neocortical organization. Z. Anat. Entwicklungsgesch. 134: 117-145.

Marin-Padilla, M. (1972) Prenatal ontogenic history of the principal neurons of the neocortex of the cat (Felis domestica). A Golgi study. II. Developmental differences and their significances. Z. Anat. Entwicklungsgesch. 136: $125-142$.

Marin-Padilla, M. (1978) Dual origin of the mammalian neocortex and evolution of the cortical plate. Anat. Embryol. 152: 109-126.

Marin-Padilla, M., and T. M. Marin-Padilla (1982) Origin, prenatal development and structural organization of layer I of the human cerebral (motor) cortex A Golgi study. Anat. Embryol. 164: 161-206.

Noback, C. R., and D. P. Purpura (1961) Postnatal ontogenesis of neurons in cat neocortex. J. Comp. Neurol. 117: 291-307.

Nowakowski, R. S., and P. Rakic (1974) Clearance rate of exogenous ${ }^{3} \mathrm{H}$ thymidine from the plasma of pregnant rhesus monkeys. Cell Tissue Kinet. 7: $189-194$.

Otsuka, R., and R. Hassler (1962) Über aufbau and Gliederung der corticalen sehesphare bei der katze. Arch. Psychiatr. Z. Neurol. 203: 212-234.

Parnavelas, J. G., and S. M. Edmunds (1983) Further evidence that RetziusCajal cells transform to nonpyramidal neurons in the developing rat visual cortex. J. Neurocytol. 12: 863-871.

Raedler, E., and A. Raedler (1978) Autoradiographic study of early neurogenesis in rat neocortex. Anat. Embryol. 154: 267-284.

Rakic, P. (1972) Mode of cell migration to the superficial layers of fetal monkey neocortex. J. Comp. Neurol. 145: 61-84.

Rakic, P. (1974) Neurons in rhesus monkey visual cortex: Systematic relation between time of origin and eventual disposition. Science 183: 425-427.

Rakic, P. (1977) Prenatal development of the visual system in rhesus monkey. Philos. Trans. R. Soc. Lond. (Biol.) 278: 245-260.

Rakic, P. (1982) Early developmental events: Cell lineages, acquisition of neuronal positions, and areal laminar development. in Development and Modifiability of the Cerebral Cortex, P. Rakic and P. S. Goldman-Rakic, eds., p. 440, MIT Press, Cambridge, MA.

Ramón y Cajal, S. (1890) Sobre la existencia de celulas nerviosas especiales en la primera capa de las circunvoluciones cerebrales. Gac. Med. Catalana 3: $737-739$.

Ramón y Cajal, S. (1911) Histologie du Systéme Nerveux de l'Homme et des Vertébrés, Vol. 2, Maloine, Paris.

Ramón y Cajal, S. (1929) Studies on Vertebrate Neurogenesis, L. Guth, transl., Charles $C$ Thomas, Publisher, Springfield, IL.

Rickmann, M., B. M. Chronwall, and J. R. Wolff (1977) On the development of non-pyramidal neurons and axons outside the cortical plate: The early marginal zone as a pallial anlage. Anat. Embryol. 151: 285-307.

Sas, E., and F. Sanides (1970) A comparative Golgi study of Cajal foetal cells. Z. Mikrosk. Anat. Forsch. 82: 385-396.

Scott, P. P. (1970) Cats. In Reproduction and Breeding Techniques for Laboratory Animals, E. S. E. Hafez, ed., pp. 192-208, Lea and Febiger, Philadelphia

Shatz, C. J. (1981) Inside-out pattern of neurogenesis of the cat's lateral geniculate nucleus. Soc. Neurosci. Abstr. 7: 140.

Shatz, C. J. (1983) The prenatal development of the cat's retinogeniculate pathway. J. Neurosci. 3: 482-499.

Shoukimas, G. M., and J. W. Hinds (1978) The development of the cerebral cortex in the embryonic mouse: An electron microscopic serial section analysis. J. Comp. Neurol. 179: 795-830.

Spitzer, N. C., and J. E. Lamborghini (1981) Programs of early neuronal development. In Studies in Developmental Neurobiology, W. M. Cowan, ed., pp. 261-287, Oxford University Press, New York.

Tusa, R. J., L. A. Palmer, and A. C. Rosenquist (1976) The retinotopic organization of area 17 (striate cortex) in the cat. J. Comp. Neurol. 177: $213-236$. 